Jpn. J. Ornithol. 48: 5-45, 1999

\title{
DNAを利用した鳥類の系統解析と分類
}

\author{
梶田学

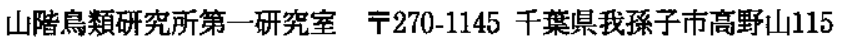

\section{Avian Phylogeny Using DNA Analysis and Taxonomy}

\author{
Manabu KAJITA \\ The Yamashina Institute for Ornithology, \\ 115 Konoyama, Abiko, Chiba 270-1145, Japan
}

\begin{abstract}
Advances in molecular techniques, particularly the development of DNA sequence determination, have led to an explosive increase in studies of avian phylogeny. To date, many of these studies have examined mitochondrial DNA (mtDNA) because it has many useful features for the study of the phylogeny of closely related taxa. Unfortunately, however, the use of mtDNA also has some problems since mitochondria are inherited maternally. Samples of blood, tissue, feather and even dried skin can be used as a source of DNA. DNA sequences are analysed in the order: extraction, amplification, sequence determination. Inferences about phylogenetic relationships from sequence data are made using an assortment of methods that include parsimony, maximum likelihood, and distance. The confidence levels of the resulting phylogenetic trees can be determined using statistical methods such as bootstrap. For the time being, it is not possible to delimit species solely on mtDNA information. There are many unsolved problems, and many fruitful areas for study in the phylogeny of Japanese birds. DNA analysis is a requisite method to solve these problems. Phylogenetic analysis using DNA sequencing will play a leading role in solving questions relating to avian evolution.
\end{abstract}

Key Words: DNA sequence, Evolution, Phylogeny, Taxonomy

1990年代の鳥類学における大きな変化のひとつとして, 鳥類の系統研究に DNA 分析の 手法を利用することが一般化し，関連の研究事例が急激に増加した事を挙げることができ る. DNA やこれにコードされたタンパク質などの分子情報から，生物の系統を推定する 学問分野は「分子系統学」と呼ばれる（長谷川・岸野 1996, 長谷部 1996). DNAなど の行子情報を用いた系統解析には，これまで系統解析に利用されてきた手法にはない利点 が数多くあり，そこから得られる成果は，鳥類の系統進化を考える上でなくてはならない 情報になりつつある，その一方で，日本及びその周辺の鳥類には，分子系統学的手法を用

注 : 本文中で用いた鳥類の和名は基本的に日本鳥学会（1974）及び山階（1986）によった. 
いて研究を行うべき課題が山積されている，しかし，国内における「鳥類分子系統学」の 発達は非常に遅れており，日本鳥学会誌へのこの分野に関連した投稿は現在まで皆無であ る. しかし，今後，国内でも多くの鳥類研究者がこの興味深い分野の研究に着手するよう になり，研究例も急速に增加すると推測される．本稿は1998年度日本鳥学会において催さ れたシンポジゥム「鳥類学におけるDNA 研究」の中での著者の発表内容が基になってい るが，「鳥類分子系統学的研究」に実際に着手する際，すぐに役立つ情報や研究に不可欠 なサンプル採取・保存の方法及び日本における今後の研究課題などについて多くの内容を 追加している。

\section{系統を知る必要性}

鳥類の各分類群の正確な系統関係を把握することは，それ自体がひとつの学問的興味の 的とすなっているが，単にそれだけではなく鳥類の多椂性と進化に関する全ての研究の基 礎となるるのである. 求受行動や膞りなどの行動形質, 環境や食物選択などの生態形質, 嘴の形状や羽色などの形態形質など，あらゆる形質の進化に関する考察を行うためには， ある 1 種だけでの考察は不可能であり, 種間比較 (分類群間比較) が必要となる (Harvey \& Pagel 1991, 粕谷 1995).この比較の対象となる種（分類群）を系統を無視して選ん だ場合，誤った結論を導いてしまうことが多い，正確な種間比較を行うには正確な系統関 係を知ることが大前提となる。

\section{DNAを使用する利点}

DNA の塩基配列デー夕は，以下にあげるような系統推定に非常に適したいくつかの特 徽を持っている. (1)非常に多くの形質情報が得られる，例えば200塩基対（base-pair= bp）の盐基配列を系統解析に使用した場合，各サイトを $1 つ$ 形質として扱うので 200 形 質を集めて解析したことになる．例えば形態形質を200集めるのは非常な困難を要する場 合が多く，それと比較すると非常に容易に大量の形質を集めて解析することができる．(2) 定量化しやすく，統計的解析が容易である．（3)異なる分類群であ同じ尺度を用いて比較す ることができる. (4)分子時計を設定することができる．塩基配列デー夕は，ある程度自然 選択に中立で，時間に比例して変異を蓄積していると考えられている．したがって，変翼 の程度を比較すれば，分類群同士がぞのくらい前に分化したのかが推定できる場合がある. また，伝統的に利用されてきた形態的形質と比べた場合，塩基配列データには研究者の主 観が入り込む余地が少なく，収敛進化をより簡単に排除できるという特徵がある. さらに， 塩基配列データはデータベース化が容易であり，実際データバンクから他の研究者が登録 した解析データを簡単に取り出すことが可能である（高木・金久 1996）.

\section{利用されるDNAと領域}

1) ミトコンドリアDNA（mtDNA）

鳥類の DNAには，核に存在する核 DNA とミトコンドリア内に存在するミトコンドリ 
ア DNA（=mtDNA）があるが, 今のところ鳥類の系統解析に利用されているのは主に mtDNA である. 鳥類の mtDNA は，2本鎖の環状DNA で, ニワトリGallus gallus で は16,775bpの長さを持つ（Desjardins \& Morais 1990)。ニワトリについては全塩基配列 (Desjardins \& Morais 1990), アヒル (ペキンダック) Anas platyrhynchosについて 66,474bpが解析されており（Ramirez et al. 1993），遺伝子の配置などあ明らかになっ ている (Fig. 1).

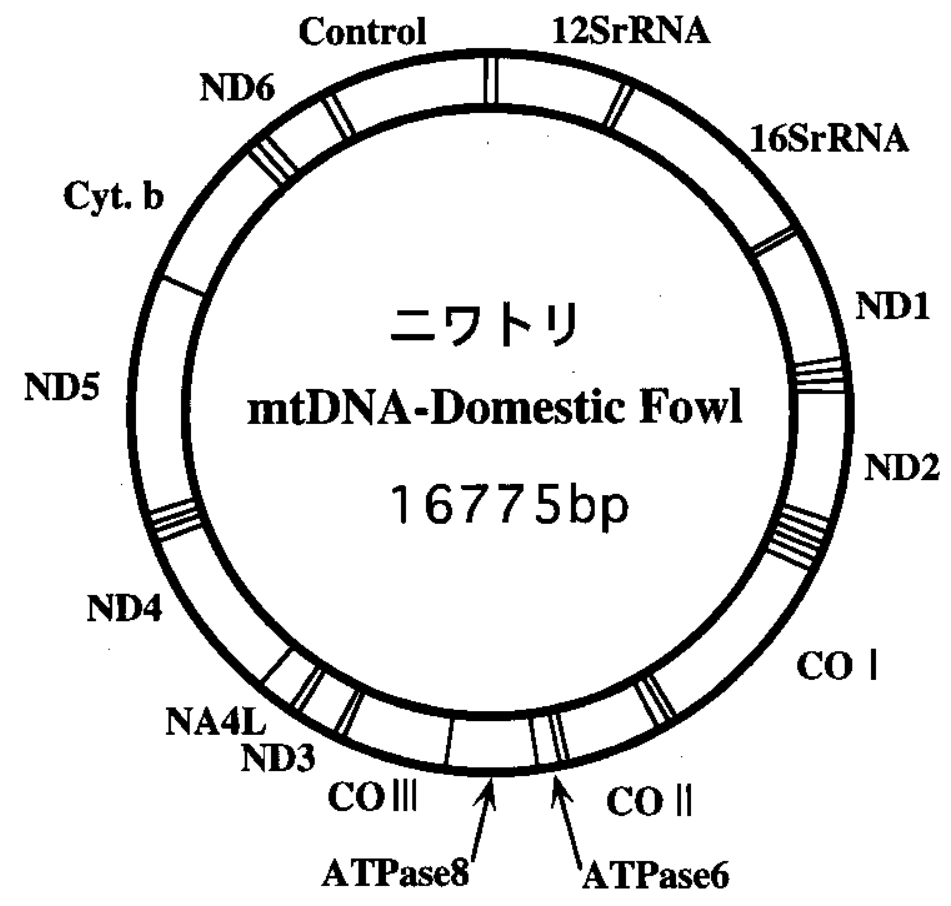

Fig. 1. Schematic diagram of the gene content and order of the chicken mitochondrial genome (Adapted from Fig. 3 in Desjardins \& Morais 1990).

ミトコンドリアは核に比べ分裂周期が早いため，単位時間あたりの突然変異の発生が多 く，生じた突然変異を修復する能力を持たない（高畑 1986）。このため核DNAに比べ mtDNAの単位時間あたりの塩基の㯰換率（=進化速度）は非常に速く，核 DNA の約 10 倍〜20倍である（Brown et al. 1979）。このため近縁種間の系統解析に使用することが できる，ただし，進化速度は mtDNA 内の領域によっても多少異なる．現在鳥類の系統 解析に頻繁に使用されているのは, 12SリボゾームRNA（12SrRNA）領域，チトクロー $\Delta \mathrm{b}$ (Cytochrome b=Cyt.b) 領域, コントロール (Control) 領域の 3 領域である. を の他の領域を使用しての研究例は今のところ非常に少ないが，今後は使用される領域の多 椂化が見込まれる，以下に良く利用される領域について解説を加える. 
（1）12Sリボゾーム RNA（12SrRNA）領域

12SrRNA 領域は約1,000bpの長さを持ち, リボゾーム（タンパク質合成に関与する細胞 小器官）の一部を構成するRNA（12SrRNA）の遺伝情報をコードしている（Desjardins \& Morais 1990). 進化速度は, ここに挙げた 3 領域の中では最も遅いと考えられており (Mindell \& Honeycutt 1990), ニホンジカ Cervus nipponにおける塩基配列の比較を行っ た例では, 12SrRNA 領域はCyt.b領域の約2.7分の 1 の進化速度を示す (Nagata et al. 1995). このため, 種よりあ上の分類階級（属，科）の系統解析に利用されることが多い が, 鳥類における害際の研究例は今のところあまり多くない (Houde et al. 1997). PCR 法で増愊を行う際にはポリヌクレオチド（一般に primer と呼ばれる）が必要となるが, この領域については幅広い分類群で使用可能な汎用性のプライマーす開発されている (Kocher et al. 1989). 分類群による塩基配列の変異はCyt.b 領域などに比べ少ないため, このような汎用性プライマーや他の分類群用に設計されたプライマーをそのまま流用しや すいという利点がある.

（2）チトクロームb (C-rtochrome b) 領域

チトクロームb 領域は $1,143 \mathrm{bp}$ 長さを持ち, ミトコンドリアの電子伝達系の反応に関 与する酵素タンパク質の 1 種チトクロームbの遗伝情報をコードしている (Desjardins \& Morais 1990). 進化速度は, 12SrRNA 領域より速く, Control 領域よりも遅い, 進化速 度が中間的であるため，主に種レベル（時に亜種レベル）の系統解析に利用されており， 現在最す多く利用されている領域である (Moore \& DeFilippis 1997). 過去の研究例が 豊富かつデータベース化されていて引用が容易にできることも Cyt.b 領域が頻繁に利用さ れる理由のひとつである. 汎用性のプライマーも開発されているが (Kocher et al. 1989), 種間での塩基配列の変異が比較的多いため, 汎用性のプライマーや他の分類群用に設計さ れたブライマーをそのまま流用できない場合がある. しかし，過去に行われた研究例が多 いので, 近緑種の塩基配列デー夕の比較により，自らの研究対象に適合するプライマーを 新しく設計することはさほど難しくない.

（3）コントロール (Control) 領域

約1,135bpの長さを持つ制御遺伝子である Cyt.b 領域や 12SrRNA 領域に比べ非常に速 い進化速度を持つ領域と考えられている（Brown et al. 1986）。これは，コントロール 領域がタンパク質などの遺伝情報をコードしていない領域（non-cording領域）であるた め (Desjardins \& Morais 1990), 笑然変異による塩基の置換を容易に固定する事による と考えられている. 進化速度が速いため主に亚種・個体群レベルの研究に利用される，過 去に行われた研究は多くないが，近年増加しつつある（Baker \& Marshall 1997）。ず に開発されたいくつかのプライマーがあるが (Quinn \& Wilson 1993, Tarr 1995, Baker \& Marshall 1997), 種間, 個体群間での塩基配列の変異が多いため, 他の份類群用に設 計されたプライマーをそのまま流用することは他の領域に比べると困難である。蓄積され た研究例も多くないため, 近縁種の塩基配列データが公表されていない場合にはプライマー 設計に時問がかかる場合がある．この点については，今後研究例が增加することで解決さ れてゆくと思われる. 
（4）その他の領域

最近では前述した 3 領域以外にも鳥類の系統解析に利用される mtDNAの領域が急速 に増加しつつあり, ND2 (Zink \& Blackwell 1998), ND6 (Moum \& Johansen 1992, Wood \& Krajewski 1996, Jones \& Gibbs 1997, Zink et al. 1997), CO I (Miranda et al. 1997), COII, ATP8 (Greenberg et al. 1998) などの蛋白質コーディング領域, tRNA ${ }^{\text {Thr, }}$ tRNA ${ }^{\text {Pro }}$ (Krajewski \& Wood 1995, Wood \& Krajewski 1996), tRNA (Greenberg et al. 1998) などのトランスファーRNA 領域の研究例がある.これらの領 域は Cyt.b と同じく主に種レべルの系統解析に使用されたるのである。ただし，ほとんよ゙ の場合，単独では使用されず，Cyt.b 領域など他の領域と組み合わせて解析されている． 進化速度などについては現在不明な点が多いが，令後情報が蓄積されるにつれて明らかに なると考えられる。

\section{2) 核 DNA}

mtDNA のみの分子データを用いて系統の解析を行った場合, 後述のような母系遗伝に 伴う問題点が生じる可能性がある．これらの問題を排除するため遗伝嵄式が mtDNA と は異なる核DNAの解析を同時に行うことが望ましい，鳥類の核DNA は両性遗伝をする ため母系遗伝に伴う問題点は生じ得ない.しかし，核 DNA は mtDNA に比べ進化速度の 遅い領域が多く，例えば類縁の遠い生物間の系統解析によく用いられる核 DNA の 18SrRNA 領域（約2,000bp）は，ヒトとアフリカッメガェルの間で $9 \%$ 違いしかない （和田ら 1992）。そのような領域を使用しても広い分類群間でほとんど同じ配列を示すた め低次分類群（種，严種）の系統解析などにはあまり役に立たない。鳥類においては， Chikuni et al. (1996）が核 DNA の18SrRNA 領域の部分塩基配列293bpを解析した研究 例がある。この研究では対象としたスズメ目20種の内 17 種で解析した部分の塩基配列が完 全に一致しており，18SrRNA 領域が近縁種間の系統解析にはあまり有効ではないことが 明らかである。

18SrRNA 領域以外では, 比較的進化速度の速い 18SrRNA のスペーサー領域（100万年 に約 $1 \%$ の塩基置換を固定する＝約 $1 \% \mathrm{MY}=\mathrm{Cyt} . \mathrm{b}$ の約半分の進化速度）や遺伝子の機 能を有していない為遗伝子領域（約 $0.2 \% \mathrm{MY}=\mathrm{Cyt} . \mathrm{b}$ の約10分の 1 の進化速度）などが候 補になると思われるが，今のところ鳥類の系統解析への応用例はないようである. 生態学 でよく利用される反復配列領域のミニサテライト（minisatellites）やマイクロサテライ ト（microsatellites）では逆に進化速度が速すぎ，個体間でも変異が検出されてしまうた め (西海 1997), 種間の系統解析などには利用しにくい場合が多い，現在のところ鳥類の 種レベルの系統解析に利用しやすい進化速度を持つ核DNAの領域は知られていないため, 実際に核 DNA の情報を検討する場合には間接的なアブローチではあるが，アロザイム （allozymes）分析（酵素タンパク質の多型を検出する手法）が使用される場合が多い. 今後利用しやすい領域が発見されれば, 核DNAを解析に用いた研究例も增加するすのと 思われる. 


\section{$m t D N A を$ 使用する场合の問題点}

1) 核に類似配列が存在する問題

核の中に mtDNA と類似する配列があることが知られている（Quinn 1997）. PCR 法 を使って mtDNAの一部を增幅する場合, 誤ってこのような核の mtDNA 類似配列を增 幅し，そのことに気づかずに解析してしまうことが考えられる。この点については mtDNA を核DNA から分離した上で PCR に使用することで防ぐことが可能である.

\section{2） mtDNAの母系遗伝に関する問題点}

細胞小器官であるミトコンドリアの持つ基本的かつ重要な特徴として,メス親からのみ 子供 $\left(\mathrm{F}_{1}\right)$ に受け渡されることがあげられる。このためミトコンドリアが保持する mtDNA あメス親からのみ子供に遭伝する性質を持つ（母系遗伝），才スの持つ mtDNA は子供には受け継がれない（異種間交雑の場合はこの原則が崩れることが知られている. 雑種判定の項参照).このため, mtDNAの各領域を用いた系統解析は, 実際にはメスの 系統 (mtDNA の系統) のみを示している.このことが鳥類の系統解析を行う際に問題と なる場合があるので, 分析結果の考察を行う際には十分な注意が必要である，この点につ いて以下に解説しておく.

（1）メスの出生地からの分散（natal dispersal）に関連する問題

メスが出生地から他地域へは分散をせず，代々そこで繁殖をくり返す習性を持ち，一方 オスは出生地から分散して他地域へ移動して繁殖を行う習性をむつ種の場合, いくつかの 地理的に隔離された個体群は，オスの移動によって個体の交流二核DNAの交流が維持さ れているため実際には仔化しない，しかし，このような種の mtDNAは，メスの交流が ないために時間と共に個体群間の相違が大きくなる。十分な時間が経過したのち、この種 の各個体群の mtDNA の塩基配列を比較した場合，実際には個体群間の交流は保たれて 続けているのにもかかわらず，mtDNA は個体群間で大きな分化を示すことになる，一般 に鳥類は，哺乳類と異なりメスが出生地から分散して繁殖を行い, オスは出生地からあま り分散しない傾向のあることが知られている (Greenwood \& Harvey 1982).このため 上記のような問題が頻繁に生じるとは考えにくいが, カモ目（Anatidae）のいくつかの 種では, メスが出生地に留まる傾向の強いことが示されている (Sowls 1955, Cooke et al. 1975, Alison 1977, Greenwood \& Harvey 1982).

標識した個体の㷌還率からメスが出生地に戻る傾向が極めて強いことが明らかになって いるハクガン Anser caerulescens で mtDNA を分析した例では, 地理的に隔離されてい る繁殖地間において mtDNAの明確な分化は検出されなかった (Avise et al. 1992).こ のハクガンの例を含め,メスの分散性の低さによって個体群間の mtDNA が分化した事 例は，少なくとも鳥類では実際には確認されていない. しかし, 理論的には起こりうる現 象である. 形態や行動などの形質が全く異ならない分類群間の mtDNAに相違が認めら れる場合には，隱蔽種 (cryptic species : 形態的には区別が困難であるにも関わらず，生 殖的に隔離されている種) であると結論する前に, メスの分散について検討を加える必要 がある. 
（2）異種間浸透（introgression）に関する問題

異種間で交雑が起こった場合, 例えばシジュウカラParus majorのオスとヤマガラ $P$. variusのメスが交雑した場合, 生まれるヒナ（F1）の核 DNA は両種のあのが混じって遺 伝しているが, mtDNA は母系遣伝するので全てヤマガラのメスから遺伝したすのである. このヒナのうちメスが成長してシジュウカラのオスと繁殖すると生まれるヒナ（ $\left.\mathbf{F}_{2}\right)$ は, やはり全てヤマガラの mtDNA を持っことになる．これを何代にす渡ってくり返すと， ヤマガラの核DNA はシジュウカラの核DNAによって薄められてしまうが, mtDNA は 薄められることなくシジュウカラの集団の中に広がってゆき，見た目はシジュウカラなの にヤマガラの mtDNAを持つ集団が生じることになる、この様な現象は mtDNA の異種 間浸透と呼ばれる. mtDNAの広まりが, 種を形成する個体群の一部に限られる場合は, 種内に大きく異なる mtDNA タイプが検出され，そのひとつが他種の mtDNAと一致す ることになる．しかし，場合によっては種内全体に他種の mtDNAが広がることがあり， この場合異なる 2 つの種の mtDNA が同じ配列を示すことになる. 異種間浸透の後, 再 び 2 種の mtDNAの分化が起こった（=交雑以降交流がなかった）場合でも分化の程度 は実際の種の分化上りる低くなるため，系統推定や分岐年代の計算に影響を与える．鳥類 で異種間浸透が実際に確認された例はないが，他の分類群ではいくつかの例が知られてい る(高㚼 1986). 形態や行動などの形質が大きく異なる分類群間の mtDNAに相違が認 められない場合には, 類縁が近いと結論する前に異種間浸透について検討を加える必要が ある.

\section{3）塩基配列の収斂進化}

mtDNAに限った問題点ではないが，塩基配列にも収斂現象が知られている. 本来, 涙 や唾液に含まれ，侵入する細菌類から体を守る働きをしている醅素（リゾチーム）が，木 の葉を食べる偶蹄類の反留動物（シカなど）とサルの 1 種では新しく消化硣素の働きを獲 得している. 新機能を獲得したリゾチームの情報をコードしている領域のアミノ酸配列は， 類縁関係のない反努動物とサルで部分的に湖たものとなっている（Stewart et al. 1987）. このように希ではあるが，分子レベルであ適応的進化により収敛が起こることは事実であ る.しかし，複数の領域を調べればこれが収斂であることはすぐに明らかとなる．また， 鳥類の系統解析に頻繁に利用される mtDNAのCyt.b, 12SrRNA, Control な゙の領域で は，今のところこのような収敛進化は検出されていない，ただし，全くないと決まったわ けではないので, 解析された系統が従来の分類と一致しない場合には収斂進化む一応考慮 すべきであろう。

\section{進化速度と分歧年代}

\section{1) 分岐年代の計算}

DNAの盐基配列を利用した系統解析の場合，分析した領域における単位時間あたりの 塩基の置換率（進化速度）が明らかであれば，分岐年代を計算することが可能である，進 化速度を求めるための基礎となっているのは主に化石資料や地史的情報である，例えば鳥 類においてよく利用されるCyt.b 領域の100万年あたりの塩基の置換率 $2 \%(2 \% / \mathrm{MY})$ 
という值も現生のガン類の分子データとその化石資料から計算されたあのである (Shields \& Wilson 1987). その他, 計算されているすのとしては八ワイミッスイ類の2.0 \%/MY (Tarr \& Fleischer 1993), ッル類の0.7-1.7\%/MY (Krajewski \& King 1996) がある. しかし，その後 Cyt.b 領域では大半の変異がコドン（codon：塩基配列がアミ） 酸に翻訳される場合の暗号，3 塩基で 1 つのコドンを形成する）の 3 番目の塩基に生じて いることが明らかになり（Edwards et al. 1991），この部分のみを用いて進化速度を計 算することも行われるようになった（例 : アホウドリ類1.58-2.86\%/MY (Nunn et al. 1996)). しかし, これらの值は化石資料などを基に推定した值であるため, 大雑把な值で あり，かなり大きな㕵差を含んでいるすのと推測される．また，次に述べるょうに，行吱 年代を計算する上で，問題となるいくつかの要因も指摘されている.

\section{2 ）分吱年代を計算する上での問題点}

分旪年代を計算する上で最も問題になるのは，分類群による進化速度の違いが存在する ことである．分類群による進化速度に違いが生じる主な原因は，分類群ごとに代謝速度が 異なることと世代交代の速度が異なることの 2 点である．基礎代謝量は一般に体の大きさ に反比例し，基礎代謝量の大きいるの（代謝速度の速いもの）ほど進化速度が速いと考元 られている (Martin \& Palumbi 1993).

世代交代の速度については，交代速度の速いものほど進化速度は速くなると考えられて いる．例えば，生まれた翌年には繁殖を開始する世代交代の速いスズメ目の鳥類と繁殖開 始に数年を要し世代交代の速度の遅いッル類では, 同じ $2 \%$ 塩基置換でも, それを生じ るのに必要な年月は同じではない（ツル類の方がより長い年月が必要である）と推測され ている (Krajewski \& King 1996).これは，ある個体に生じた淘汰に中立な突然変異が 集団全体に搪がる（固定される）のに必要な時間が, 平均 $4 \mathrm{Ne}$ 世代（ここでの $\mathrm{Ne}$ は有効 な集団の有効な大きさで，大雑把にいえば 1 世代あたりの繁殖個体数)であることによる (木村 1988). したがって, 突然変異の生じる率と繁殖個体数 $(\mathrm{Ne})$ が同じ 2 つの種を比 較した場合, 世代交代の速い種のほうが突然変異が固定されるのに必要な絶対時間は短く なる二進化速度が速くなる（この点を考察するのに不可欠な各種鳥類の繁殖開始年齢は Sibley \& Ahlquist 1990 の Table 16 にまとめられている).

また，同様の原理で世代交代の速度が同じであれば， 1 世代あたりの繁殖個体数がより 少ない（Neが小さい值）種の方が, より進化速度が速くなると考えられる. 加えて, 個 体数の多い個体群よりも個体数の少ない個体群の方が突然変異が固定される率が高い場合 のあることあ指摘されている(Ohta 1992). 歴史的にボトルネックや創始者効果の働い た可能性のある個体群や種の系統を解析・分岐年代の計算をする場合には注意が必要であ る(本号, 高木論文を参照).

以上のことから，鳥類の他の分類群で計算された進化速度を, 自らの研究対象にあては めて分岥年代を計算する場合には, 両者の代謝速度や世代交代速度及び個体数が極端に大 きく異ならないことを確認する必要がある.

また, 理由は明らかではないが, 鳥類は哺乳類などと比較して進化速度が遅いことも指 摘されている (Kessler \& Avise 1985, Martin \& Palumbi 1993, Nunn et al. 1996). このため晡乳類で計算された進化速度（例えぱ, Cyt.b領域でコドンの 3 番目の進化速度 
10\%/MYなど）を鳥類に利用する場合には注意が必要である.

また, 塩基の突然变異にはトランジッション（transition=TS : プリンが他のプリンに, またはピリミジンが他のピリミジンに置き換わる点突然変翼, すなわち $\mathrm{G}$ が Cに変異す る場合とその逆，A が Tに変異する場合とその逆を全てトランジッションと呼ぶ）と卜 ランスバージョン（transversion＝TV：プリンがピリミジンに，またはピリミジンがプ リンに置き換わる点笑然变異, すなわち $\mathrm{G} か ゙ \mathrm{~T}$ あしくは変異する場合とその逆，Cが $\mathrm{T}$ むくはAに変異する場合とその逆を全てトラスバージョンと呼ぶ）があることが知 られており．TSとTVの起こり易さの違いあ分肢年代を計算する上での問題となる．最 初に例として舉げたガン類やハワイミッスイ類，ッル類の進化速度は，TS と TV 両方の 塩基置換をあわせて計算したものである．実際には同じ $2 \% の$ 相違です，含まれる TS， TV の割合によって分化するのに必要な時間は変わってくる可能性が高い（9-(3)重みづけ の問題の項を参照).

この他，塩基の多重置換の影響も問題となる場合が多い，塩基配列の分化程度が大きい 分類群間では多重置換が起こっている可能性が高く、計算された分岐年代は実際よりも過 小評価になると考えられる（9-(4)多重置換の問題の項を参照）。また, DNA 解析によっ て検出される塩基配列の分化は，そのうちのかなりの量が種分化や完全な地理的隔離より あ前に起こった可能性があることも指摘されている（Avise \& Ball 1991,. Lynch \& Jarrell 1993).

このような様々な不確定要素が知られているために, 計算された分肢年代の值は信頼性 の低いあのとなっている. 多くの論文で，一応分岐年代が計算されているにす関わらず， 地史的情報と重ね合わせた考察がほとんど行われていないのはこのためであろう.

\section{mtDNAの雑種判定への利用}

雑種判定は系統解析と直接の関係はないが, 対象となる分類群の中に雑種の可能性のあ るサンプルが湿じっている場合，必要となるテクニックである．新たに発見された種が雑 種か否かが問題となる場合す多い，ただし，容易に判定ができるのは雑種 1 代目（F1）の みである，実例としては1982年に独立種として記載されたCox's Sandpiper Calidris paramelanotos (和名末定) がアメリカウズラシギC. melanotos とサルハマシギC. ferruginea の雑種である事が判明した例がある (Christidis et al. 1996a). 母親となっ た種の特定には mtDNA が利用される．雑種と思われる個体の mtDNA の塩基配列と一 致する種を見つけ出せばよい，当然種レベルで変異の検出できる領域を使用する必要があ る. Cox's Sandpiper の場合は Cyt.b 領域の部分塩基配列288bpが使用され，サルハマシ ギの Cyt.b 領域の配列と一致することが確認された. 父親の特定には今のところアロザイ ム（酵素タンパク質の多型）が利用されている，ただし，最近の研究ではマウスやショウ ジョウバェなどにおいて異種間または亚種間交雑の場合, 雑種 1 代目に限り父親由来の mtDNA が子供に遺伝し，母親由来の mtDNA と同居する例のあることが明らかとなった （金田・米川 1998）．鳥類での事例は今のところ確認されていないようだが，発見された 場合 Cox's Sandpiper で使用された手法は今後見直しを迫られる可能性もある. 


\section{サンプルの採取と保存}

現在利用できる主なサンプルは，組織及び血液，羽毛などである．いずれのサンプルむ 得られるDNA は全く同じものであり，PCR 法を利用する系統解析の手法全てに利用可 能である.これらのサンプルはいずれる個体を生かしたまま採取することが可能である. なお，生体からのサンプル採集には環境庁への学術申請を行い許可を受けることが必要で ある.

博物館などに保存されている標本（剥製，液浸標本）からDNA を抽出し分析に利用す ることも可能である (Ellegren 1994, Thomas 1994). また, 国外には鳥類の組織, 血液 を保存し研究者に提供するバンクも存在する（具休例については，6）サンプルバンクの 利用の項参照).

ここでは著者が実際に使用している方法を中心に手法の説明を記す．ここに挙げた方法 で採取・保存したサンブルは; 最す一般的なフェノール・クロロフォルム法での DNA 抽 出には適しているが, 近年各製薬会社等から発売されているDNA 抽出キットを利用して の抽出には適さない場合がある。このようなキットを利用する場合は，それぞれに適した サンプル採取・保存法を使用する必要がある．また，サンプル採取に使用する器具などは 他個体の DNA の混入を避けるため，個体毎に取り替える必要がある，保存には㙎菌済み のチューブやガラス瓶，ビニールバックを使用する．ただし，冷凍保存には耐冷凍性のチュー ブなどを使用しなければならない，冷凍保存にはディープフリーザー $\left(-80^{\circ} \mathrm{C}\right)$ あしくは 液体室素中 $\left(-196^{\circ} \mathrm{C}\right)$ が適している．野外でのサンプル採取及び運搬に使用できる小形

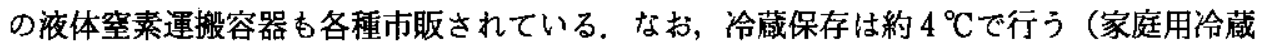
庫の冷藏室で可能).

\section{1）血液サンプル}

個体に与える影響を最低限に抑え，分析に十分な量のDNA を採取するためのサンプル としては血液が最も適している，簡易 DNA 抽出キットも多種類が市肘されており利用し やすい，鳥類は赤血球に核が存在するため，赤血球に核を持たない哺乳類に比べ少量の血 液で大量のDNA を得ることができる（西海 1997）。しかし，これは核DNAについての み言えることで，鳥類でも赤血球はミトコンドリアを持たず，白血球などにのみミトコン ドリアを有するため mtDNAについては採取できる量に哺乳類との間で大きな違いはな い.

採血は尺側皮静脈（一般的には wing vein=翼下静脈と呼ばれる）から行うのが一般的 である．また，爪の先端部を切り取り，毛細血管からしみ出た血液を採取する方法る知ら れている.この他に，頚静脈や心葴（Utter 1971）から血液を採取することる可能だが， 熟練を要する上，個体への影榔す大きいため一般的には使用されていない．大量の血液を 採取する場合には注射器を用いる場合が多いが（酒井 1997），PCR 法を利用した系統解 析を行う場合, 必要な DNA はそれほど多くないので, 毛細管を使用する方法が一般的で ある．採血量については通常脂肪のない状態での体重の $1 \%$ 程度にとどめるのがよいとさ れるが (Stangel 1986, American Ornithologists' Union 1988, 西海 1997), PCR 法を 利用する系統解析には通常70 140 $\mu$ 程度 ( $75 \mathrm{~mm}$ 毛細管 $1 \sim 2$ 本) 採取すれば十分で 
ある.

一般的な翼下静脈からの採取法としては，70\%エタノールをしみこませた脱脂綿で翼の 下面 (时の部分) を拭き，翼下静脈を露出させる（Fig. 2). 血管に隇菌した注射針で小 さな穴を開ける．しみ出た血液を毛細管を押しつけて採取する，大抵の場合，出血はすぐ に止まるが，止まらない場合は脱脂綿などで圧迫止血を行う．使用する注射針のサイズは 小形の鳥では26Gすしくは27Gが適している（G=ゲージ, 数字の大きい方が針の径が細 い. $27 \mathrm{G}=$ 直径 $0.4 \mathrm{~mm}$ ). また，毛細管はへパリン処理（血液の凝固を防ぐ）したすのを 用いる場合が多いが，作業を短時間で行えばへバリン処理をしていない毛細管を用いてす 血液凝固を防ぐことができる．また，DNA 抽出キットによっては，へパリンの使用不可 のものもあるので注意が必要である.

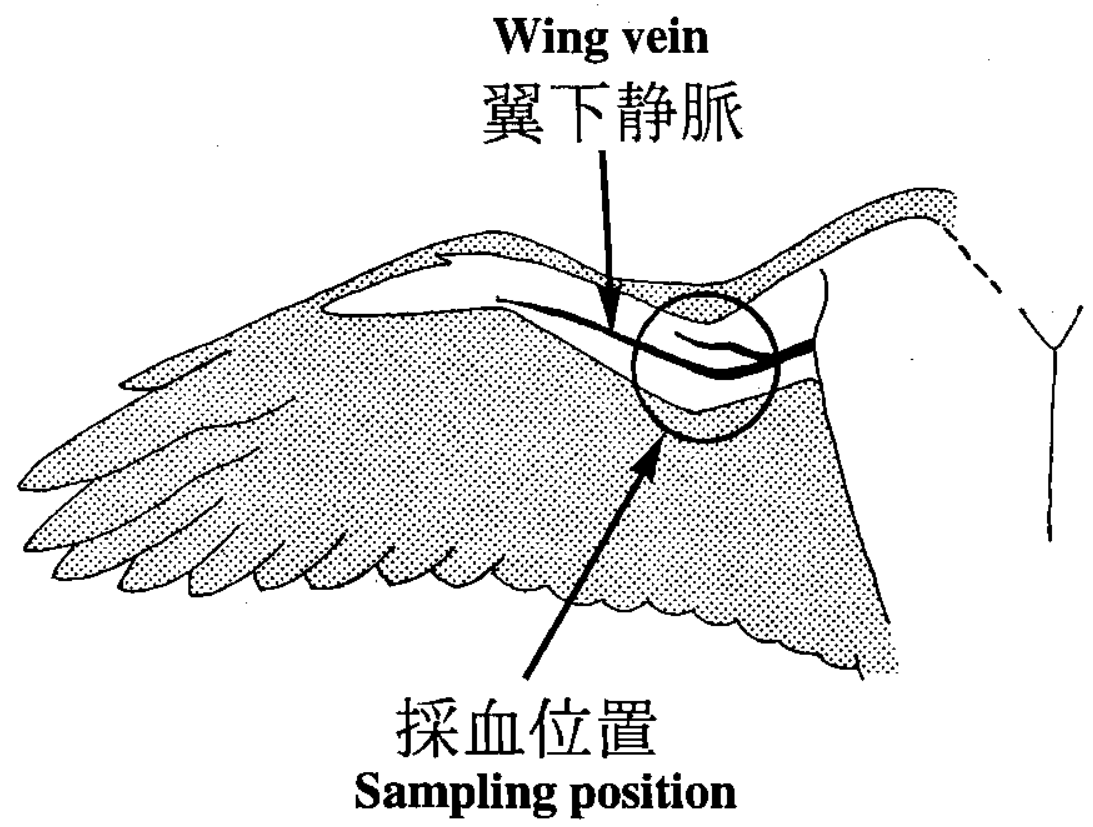

Fig. 2. The underwing vein of birds and the sampling position.

採取した血液は血液保存用の緩衝液に入れて冷蔵もしくは常温保存する，保存用緩衝液 の組成は0.01M Tris, $0.01 \mathrm{M} \mathrm{NaCl}, 0.01 \mathrm{M}$ EDTA, $1 \%$ n-lauroylsarcosine, pH8.0 (Seutin et al. 1991). その他にむいくつかの保存液が開発されている (Seutin et al. 1991, Dessauer et al. 1996). 保存用緩衝液が入手できない場合は高純度エタノール (99.5\%) を保存液として利用することができる（常温で保存可能），保存状況で変化する ことす考えられるが保存用緩衝液では最低でも半年（西海 1997），エタノール中では少な くとあ数年間は保存可能である. 


\section{2) 羽毛サンプル}

羽毛自体は基本的に死細胞で形成されているため, DNAを採取しても断片化している 場合が多いが，皮扂と接合していた部分の羽軸基部には生細胞が付着しているため，この 部分からは完全な DNA が得られる．個体に与える影響は最も少ないが，得られる DNA 量は血液や組織に比べ少量である（Taberlet \& Bouvet 1991）：採取する羽毛の部位は基 本的にどの部分でも問題がないが，小形の体羽よりも風切羽や尾羽など大形の羽毛の方が 多くの DNA を抽出できる可能性が高い (Pasquet 1998, Srikwan \& Woodruff 1998). しかし，体羽 1 枚から抽出されたDNAで分析が行われた例あある（馬場 1996, Murata et al. 1998). 換羽期にみられる成長途中の羽毛からはより多くの DNAの採取が可能で ある(西海 1995).

採取法としてはピンセットなどで引き抜いた羽毛を個体毎に $99.5 \%$ エタノル中（70\% 程度であ可能）に入れ, 冷蔵または常温で保存する. 生細胞の付着している羽軸の先端を 污染しないように注意することが必要である，エタノール以外では，組織を保存する際に 使用される緩衝腋（Seutin et al. 1991，Dessauer et al. 1996）を利用することができ る．また，冷東保存する場合は緩衝液などを利用する必要はない，腐敗に注意すれば，常 温でも保存可能と思われるが，DNA の収量が減少する可能性がある.

\section{3 ）組織サンプル}

基本的に体のどの部分の組織からでもDNAの抽出は可能であるが, 現在よく利用され ているのは，胸筋 (大胸筋) と肝㼄である，胸筋の細胞は大量のミトコンドリアを含むた め mtDNAを多く得ることができ，肝臟からは主に核DNA を大量に抽出することができ る.ただし，量的な違いはあるものの，どちらの組織からあ核DNA， mtDNA の両方を 得ることができるので，PCR 法を利用する場合，このような違いはあまり問題にはなら ない，サンプルを埰取する場合には多くの場合対象とする個体を死亡させなければならな い，死亡させた個体からはなるべく早くサンプル採取を行う必要がある．これは，死亡し た個体では DNA 分解醉素の㗢きで速やかにDNA の分解が起こるためである．死亡した 後, 冷凍と解凍をくり返した場合すDNAは分解されることが多く, 博物館などに運び込 まれる弊死体からサンプルを採取する場合などには注意が必要である，腐敗が進んだ場合 にはDNAの採取が困難である場合が多い。

採取法としては滅菌したメス，八サミなどを用いて必要な組織を切り出す。採取する量 は数 $\mathrm{g}$ 程度（実際には小指の頭程度）で十分である．切り出した組織は，ハサミで細かく 裁断して99.5\%エタノール中に常温または冷蔵保存する．裁断せずに保存すると組織の表 面だけがエタノールで固定され，内部が固定されない可能性があるので注意が必要である. 冷涷保存の場合は裁断する必要はない，冷涷保存された鮮度の高い組織は DNA 分析だけ でなくアロザイム分析にも利用可能である（アロザイム分析に利用する場合，胸筋，心䈘， 肝襪が揄っているのが望ましい). なお，個体を死亡させずに筋肉を採取する方法も報告 されており（Baker 1981），日本でもオオヨシキリで実際に武行され，翌年の鲤還率に影 響がなかった例が知られている(上田惠介 私信). しかし，この方法は普及せず現在では ほとんど使用されていない。 


\section{4) 標本からのサンプル採取}

博物館などに保存されている各種の標本からDNA 抽出を目的とするサンプルを採取す ることは，研究対象とする分類群の捕蒦が難しい場合や絶隇鳥を研究する際などに行われ， 成果む上がっている（Table 1)。しかし，標本から採取できるDNA量は生体からのサン プルに比べ少量で，しかる細かい断片に分断されている場合が多い（Thomas 1994）。 ま た，現在のところ標本を全く破買せずにDNA を採取する事は不可能であることから，標 本（特に絶滅鳥や稀少鳥の標本）の安易な利用は避けるべきである，鳥類の場合，利用さ れる標本は主に乾燥標本 (本剥製，研究用仮剥製）と液浸標本である，モアなどの絶堿し た鳥類の系統関係を研究する際に骨標本からDNA を採取した例（Cooper et al. 1992, Cooper 1994）もあるが，少なくとも鳥類では一般的ではない.

Table 1. Example of avian phylogenetic studies retrieving DNA from museum specimens.

\begin{tabular}{|c|c|c|}
\hline $\begin{array}{c}\text { Taxon } \\
\text { 対象とする分類群 }\end{array}$ & $\begin{array}{c}\text { DNA source } \\
\text { 使用されたサンプル }\end{array}$ & $\begin{array}{c}\text { References } \\
\text { 文献 }\end{array}$ \\
\hline $\begin{array}{l}\text { Podica senegalensis } \\
\text { アフリカヒレアシなど }\end{array}$ & $\begin{array}{l}\text { muscle, skin, feathers } \\
\text { 乾燥標本の筋肉, 皮席, 風切羽 }\end{array}$ & Houde \& Braun (1988) \\
\hline $\begin{array}{l}\text { Laniarius turatii } \\
\quad \text { ニシャブモズなど }\end{array}$ & $\begin{array}{l}\text { skin } \\
\text { 仮剥製の皮席 }\end{array}$ & Smith et al. (1991) \\
\hline $\begin{array}{l}\text { Hirundo rustica, Ficedula hypoleuca } \\
\text { ッバメ, マダラヒタキ }\end{array}$ & $\begin{array}{l}\text { one feather } \\
\text { 仮剥製の羽毛1枚 }\end{array}$ & Ellegren (1991) \\
\hline $\begin{array}{l}\text { Anomalopteryx } \\
\text { モアなぞ }\end{array}$ & $\begin{array}{l}\text { bone, dry tissue } \\
\text { 骨, 乾燥した組織 }\end{array}$ & Cooper et al. (1992) \\
\hline $\begin{array}{l}\text { Geopsittacus occidentalis } \\
\text { ヒメフクロウインコ }\end{array}$ & $\begin{array}{l}\text { one feather } \\
\text { 仮剥製の翼の羽毛 } 1 \text { 枚 }\end{array}$ & Leeton et al. $(1993,1994)$ \\
\hline 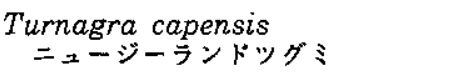 & $\begin{array}{l}\text { unknown } \\
\text { 剥製(部位不明) }\end{array}$ & Christidis et al. (1996b) \\
\hline $\begin{array}{l}\text { Puffinus assimilis } \\
\text { セグロミズナギドリなど }\end{array}$ & $\begin{array}{l}\text { one feather } \\
\text { 仮剥製の羽毛1枚 }\end{array}$ & Austin (1996) \\
\hline $\begin{array}{l}\text { Lanius ludovicianus } \\
\text { アメリカオオモス }\end{array}$ & $\begin{array}{l}\text { leg skin } \\
\text { 仮剥製の脚の裹の皮底 }\end{array}$ & Mundy et al. (1997) \\
\hline $\begin{array}{l}\text { Philortyx fasciatus } \\
\text { ヨコフウズラなど }\end{array}$ & $\begin{array}{l}\text { unknown } \\
\text { 仮剥製(部位不明) }\end{array}$ & $\begin{array}{l}\text { Zink \& Blackwell } \\
\text { (1998) }\end{array}$ \\
\hline $\begin{array}{l}\text { Dendronanthus indicus } \\
\text { イワミセキレイ }\end{array}$ & $\begin{array}{l}\text { leg skin } \\
\text { 仮剥製の脚の重の皮虔 }\end{array}$ & $\begin{array}{l}\text { Voelker \& Edwards } \\
\text { (1998) }\end{array}$ \\
\hline $\begin{array}{l}\text { Sitta frontalis } \\
\text { アカハシジジゥウカラなど }\end{array}$ & $\begin{array}{l}\text { abdominal skin } \\
\text { 仮剥製の腹部の皮店 }\end{array}$ & Pasquet (1998) \\
\hline
\end{tabular}

（1）乾燥標本からのサンプル採取

乾嬠標本（本剥製，研究用仮剥製）からのサンプルとしては羽毛と皮店が利用しやすい， 羽毛の基本的な採取法は，生体からの場合と変わらない，実際にアジアヒレアシ Heliopais personata (Houde \& Braun 1988) やヒメフクロウインコ Geopsittacus occidentalis (Leeton et al. 1993) などで利用され，DNA 採取及び分析に成功した例が ある. また，保存状態にすよるが100年以上前に作成された標本の羽毛からあ DNAの採 取は可能であることが確かめられている(Ellegren 1991).

皮庙については基本的にどの部分です利用できるが，標本の見た目が損なわれないよう 
な場所（腹部の縫い合わせ部分付近や脚の裹）から採取することが多い (Smith et al. 1991, Mundy et al. 1997, Pasquet 1998). 採取量は腹部の皮席で $8 \times 3 \mathrm{~mm}$ (Pasquet 1998)，脚の裹の皮虎で1.5×1.5mm（Mundy et al. 1997）程度で分析が可能であること が確認されている.ただし，DNA 採取量は，標本の保存状態などによって大きく変化す る可能性がある.

\section{（2）液浸標本からのサンプル採取}

液浸標本のうちエタノールで保存された標本からは, 状態の良いDNAが得られること が知られている (Thomas 1994)。一方で, 博物館などで一般的に使用されているホルマ リンで固定された標本からはPCR 法に使用できるDNA 採取が難しいことが知られてい る.ただし，ェタノールで置換した後にDNAの抽出及び增幅に成功した例が，魚類のミ ナミトミョPungitius kaibaraeなどで知られている（高田 1995）．その他の各種の液浸 標本用保存液が DNA 抽出及び PCR 法による増幅に与える影響は今のところあまり良く 判っていない.

\section{5) 採取するサンプル数}

採取するサンプル数に決まった値は存在しない，基本的に集めるサンプルは母集団の变 異を反映しているすのでなくてはならない，母集団の遗伝的变異の幅が大きければ多くの サンプルが必要になる. 母集団の変異の幅は, 分類群によっても異なるが, 解析に使用す る領域によってあ異なり, 進化速度の速い領域ほど遅い領域に比べ変異の幅が広く, サン プル数を多くしなければならない.これまでに行われた系統に関する研究では, 少数のサ ンプルに基づくあのがほとんどであった。 ただし，最近の研究ではサンプル数の增加が認 められ, Helbig et al. (1996) は, チフチャフ Phylloscopus collybitaの Cyt.b 領域の 解析で, 1 亜種最大 26 個体を解析している，同研究では20個体以上の解析を行うことがで きた分類群については母集団の変異の愊を十分に表していると結論づけている.

サンプル数は多ければ多いほどよいというわけではなく, 必要十分な量を得る事が重要 である. 適切なサンプル数を決めるには，対象とする分類群の解析を行って対象とする領 域の变異の愊を確認し, 対象とする分類群の個体数や分布の広さや隔離の程度などす考慮 に入れた上で，更にサンプリングを行うか否かを判断する必要がある.

\section{6) サンプルバンクの利用}

現在いくつかの国の大学や博物館が自らの保存している組織, 血液などのサンプル及び 抽出斉みのDNA コレクションを研究者に提供している，鳥類ではカリフォルニア大学バー クレー校の Museum of Vertebrate Zoology やコペンハーゲン大学の Department of Population Biology and Zoological Museum がサンプルの利用ガイドラインやデータ ベースをインターネット上に公表している (Arctander \& Fjeldså 1994). 入手しにくい 国外の鳥類のサンプルもこのようなサンプルバンクを利用すれば比較的容易に入手が可能 である.なお, 上記 2 ヶ所を含め鳥類のサンプルを保存・提供している機関の一覧表は Dessauer et al. (1996) に揭載されている. 
7) DNA 研究の裹付けとなる標本 (voucher specimens)

DNAによる系統解析を行う場合，DNAの裏付けとなる標本の採取，すなわち分析す るDNAの持ち主である個体を採集し標本（仮剥製標本, 液浸標本など）として組織サン プルなどと共に保管しておくことは非常に重要である (Winker et al. 1996). 畩付けと なる標本が存在することで種及び亚種の誤判定の防止, さらには, 遗伝子解析の結果を形 態の面から再検証できるなどの利点がある．稀少な鳥類の場合など標本を採集するのが非 常に困難な場合もあるが, 少なくとも分類や系統推定を最終目的とする研究の場合はある 程度の標本の採集は必須である，博物館などに届けられた弊死鳥を利用して研究を行う場 合などにもサンプルと標本の整合性を保つ必要がある.

\section{DNA 分析の手法}

DNAの分析は，(1)野外から持ち㷌ったサンプルからのDNA 抽出，(2)解析する領域の 堌幅, (3)塩基配列の解析の順で行われる. 各段階で使用される手法については, 村松 (1990), 中山・西方 (1995a， b), 中山 (1996) に実験操作法の説明があるので, ここで は詳細な記述はせず, どのような手法が使われるかのみを簡単に記述する.

\section{1） DNA の抽出}

採取したサンプルからの DNA の抽出法としてはタンパク質分解酵素（プロテナーゼ $\mathrm{K}$ など）を作用させたのち、フェノール・クロロフォルム法によってDNAを精製する手法 があっとも一般的で汎用性が高い。なお, エタノールに保存していたサンプルは, デシケー 夕内で乾燥させるなどしてェタノールを完全に除去してから抽出を行う必要がある. また， 羽毛からの DNA 抽出にはプロテナーぜ Kの 代わりに Celex ${ }^{\mathrm{R}} 100$ を使用する場合が多い (Murata et al. 1998). 組織や血液からは短時間でDNA抽出を行うことができる DNA 抽出キットが各社から市販されている.これは, 抽出に使用する薬品などをセットにした あので，実験手順や使用する薬品，サンプルの保存法などキットによって異なる場合が多 い. 薬品の調整などをする必要がなく, 長くとす数時間で DNA 抽出が可能であるなど利 点は多い。ただし，指定された以外の方法で保存されていたサンプルについては DNA 抽 出が不可能な場合があるので注意が必要である.

\section{2) DNA の增幅}

サンプルから抽出されたDNA は，核DNA と mtDNA が混合された状態になっている (total DNA). DNAの分析を行う場合, まずこの状態の DNAから塩基配列を決定した い領域の DNA のみを大量に増幅する（コピーを作る）ことが必要となる．DNAの增幅 には，大腸菌などの DNAに目的となるDNA領域を組み込んで增幅させる方法と試験管 内で無生物的に増幅を行う方法（PCR 法 polymerase chain reaction）があるが, 後者の ほうが簡便で処理速度む速いため利用しやすい. PCR 法を実際に行うには, サーマルサ イクラーなどと呼ばれる専用の装置が必要であるが, 近年は安価となり各器機メーカーか ら市販されているので入手は容易である. PCR 法で增幅を行う際に必要となるプライマー については, 各研究事例を参考にするか, データベース上からいくつかの種の塩基配列デー 
タを引用して設計する必要がある，設計したプライマーは，専用の機器があれば個人的に 作成することも可能であるが，専門の業者に依頼して合成してあらうのが一般的である.

\section{3） DNAの情報を読みとる手法}

PCR 法などで増幅された DNA は，系統解析に利用するために塩基配列の読みとり （ダイレクトシークェンシング）が行われる．塩基配列を直接読みとる方法以外の DNA 分析法としては, DNA-DNA 交雑法, 制限酵菜断片長多型の検出法がある. それぞれの 手法については石田 (1996) に一般的な解説があるので, これらの手法の変遷などについ てのみ簡単に述べる.

(1) DNA-DNA 交雑法 (DNA-DNA hybridization)

DNA-DNA 交雑法は1970年代から1980年代にかけて精力的に鳥類の系統解析を行った Charles G. Sibley らが使用した方法で，主に上位の分類群（亜目から属）において様々 な新知見が得られている，その成果は Sibley \& Alquist（1990）にまよめられており， 日本でも盛んに紹介され非常に有名な手法である（柿沢 1991, 石田 1996, Sibley 1997). この手法では，まず比皎したい種から得た二本鎖 DNA を熱することにより分離させ一本 鎖 DNA を作る．できた一本鎖 DNA を巽なる種間で相同性を利用して結合させ DNAの 雑種を形成させる，その上で雑種 DNA の熱安定性を測定することによって，両種の DNA の塩基配列の差異を推定する．特殊な実験装置が必要であることや実験設定の再現 が難しいこと，新しい手法の発達などにより現在ではほとんど使用されておらず（Fig. 3), 今後日本で利用される可能性は極めて低い。

（2）制限酵素断片長多型

(RFLP = restriction fragment length polymorphism)

DNA-DNA 交雑法に変わって1990年代初頭に一般化したのが制限酵素断片長多型を検 出する方法である. RFLP と呼ばれるこの手法には, 制限酵素 (restriction enzyme) と 呼ばれる酵素を利用する．制限酵素はDNAの二本鎖を決まった配列（認識配列）のある 場所で切断する動きを持つ（例：Alu I という名の制限醭素は AGCT という配列を認識し て Gと Cの間で切断する). 認識配列の違いにより 200 種以上が知られており，種類数は 現在香增加している，一覧表は各製薬会社のカタログや中山・西方（1995b）に掲載され ている. 解析したいDNA 領域に制限醅素を作用させ，DNA が切断されるパターンを電 気泳動によって検出し, 分類群間でこのパターンの違いを比較する. 多種の制限酵素を使 用することで間接的に分類群間の塩基配列の違いをかなり正確に検出することができ，薬 品の価格す安価で実験に特別な設備も必要でないなどの利点から，1990年代前半には鳥類 の分子系統学的研究に多用された（Fig. 3). しかし，間接的な検出法であるため情報の 損失が多く，盐基配列を直接読みとるダイレクトシークエンシングが広まるにつれ系統解 析には急速に使用されなくなり，現在ではほとんど使用されなくなっている（Fig. 3).

（3）塩基配列の決定 (nucleic acid sequencing, direct sequencing)

1990年代半ば以降普及し今後も主流となると思われる手法が，直接塩基配列を読みとる 


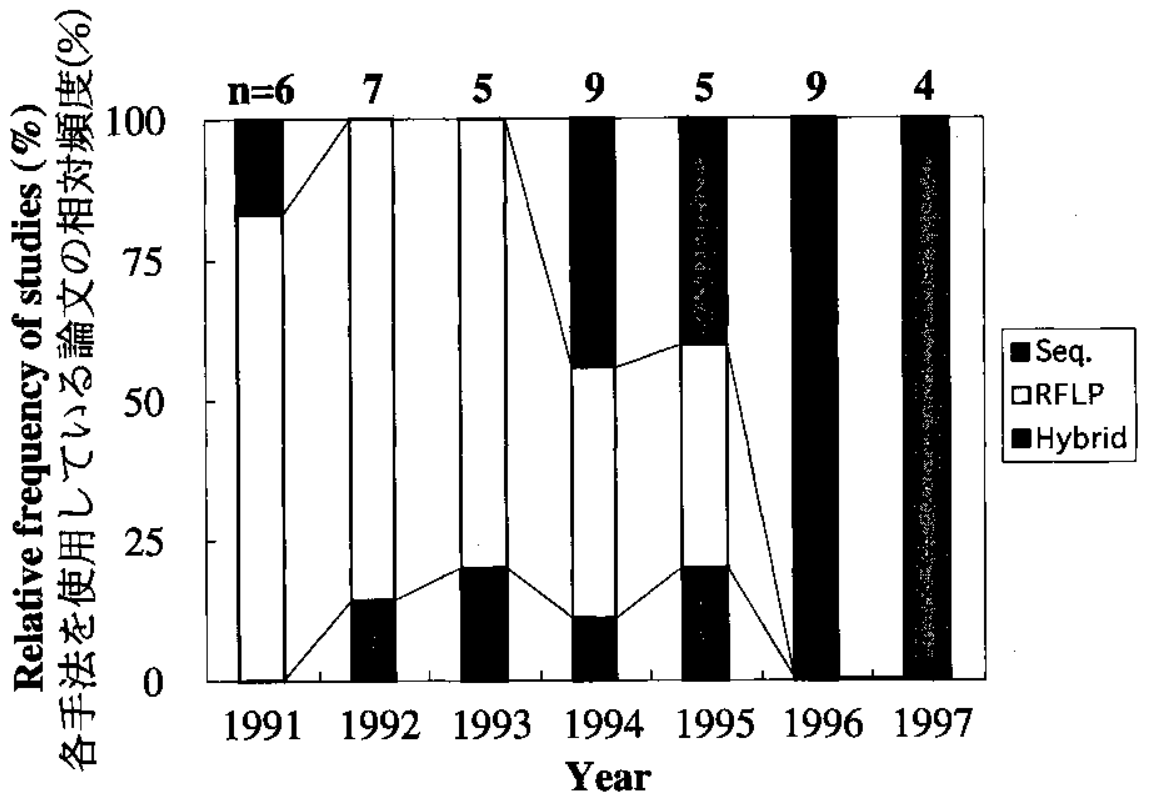

Fig. 3. Annual change in the relative frequency of the DNA analysis method used for avian phylogenetic studies, 1991 to 1997. Studies were made of three international journals of avian science: The Auk, The Condor, Ibis. Seq: Direct sequence method. RFLP: Restriction fragment length polymorphism method. Hybrid: DNA-DNA Hybridization method.

ダイレクトシークェンシング (direct sequencing, nucleic acid sequencing) である. 現 在, 塩基配列を読みとる方法として主に使用されるのははヌクレォチド類似体と DNA ポ リメラーゼを用いたダイデオキシ（dideoxy）法（またはサンガー法と呼ばれる）である. 分析対象とする領域の一次構造である塩基配列を直接読みとるので RFLP 法に比べ情報 の損失は極端に少ない. 分析結果は A, G, C, T の 4 塩基記号の羅列で示されるため, 他の分類群の分析結果との比較, 分化の程度の定量化, 系統推定ソフトへの読み込み, デー タベースへの登録・引用なども非常に容易である.

ダイデオキシ法の基礎となるPCR 法の普及, ダイデオキシ法に䖢光色素を使用する技 術の一般化（かってはRIを使用する必要があった）とダイデオキシ法で処理した結果を 電気泳動を用いて自動解析するオートシークエンサーと呼ばれる装置の普及によって, 塩 基配列を直接読みとる手法は爆発的に広まり, 見在の分子系統学分野では, それ以外の手 法で DNA を分析している研究例をみつけることが困難になりつつある（Fig. 3). 近年 の研究では, 以前よりあ長い塩基配列を系統解析に用いる傾向がある (Fig. 4).これは, オートシークェンサーの性能が向上し，一度に読みとれる塩基配列の長さ（塩基対数）が 增加していることに加え，少数の塩基配列データから解析される系統関係は信頼性が高く ないと考えられているためである. 


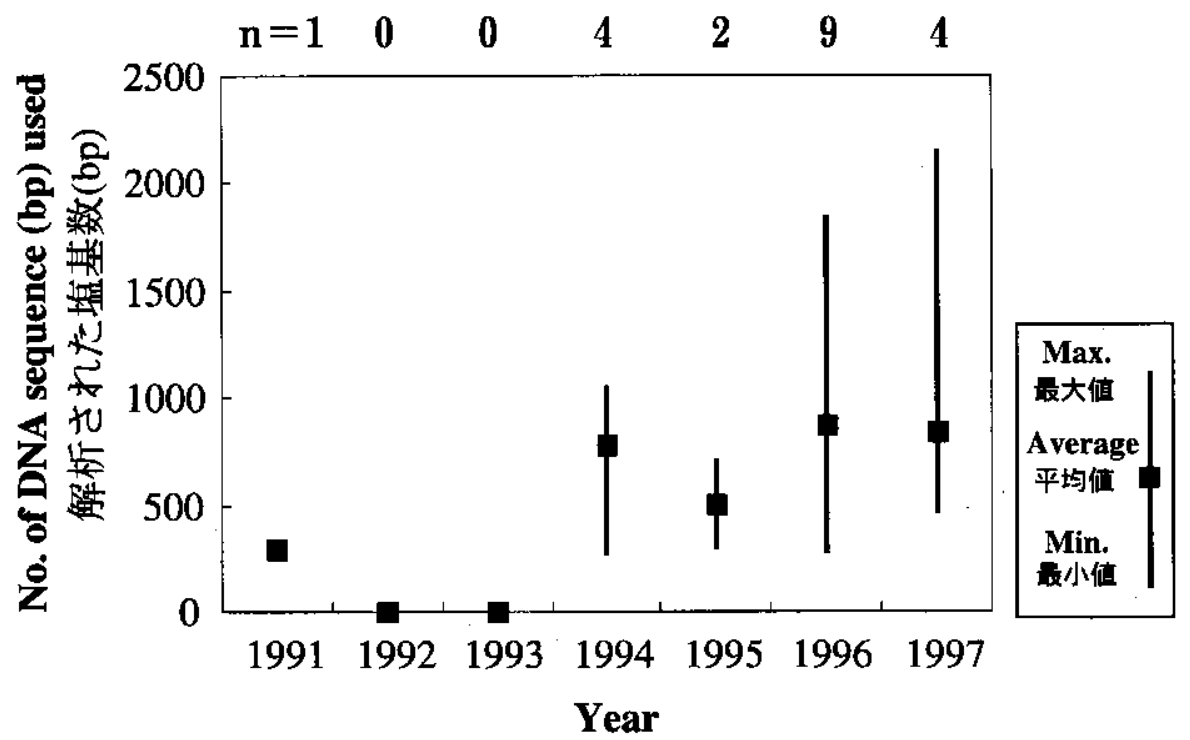

Fig. 4. Annual change in the number of DNA sequences (bp) used for avian phylogenetic studies, 1991 to 1997 . Studies were made of three international journals of avian science: The Auk, The Condor, Ibis.

\section{系統推定と系統樹の作成}

系統推定法や系統樹作成法及び得られた系統樹の信頼性の検定など，分子系統学的研究 に用いられる一連の手法は，その数す多く，原理や計算法を理解することす容易とは言い がたい．しかし 最近この分野に関する解説著が日本語で出版されたことにより（長谷川・ 岸野 1996，三中 1997)，理解のし易さは格段に向上した，分子系統学で使用される于法 は，現在も改良が続けられており，ここで紹介する手法が，今後す継続して利用され続け る保証はない，系統学（分子系統学を含む）に携わる研究者は，系統推定法などの改良に 常に注意を払う必要がある.

DNA-DNA ハイブリダイゼーション, RFLP，ダイレクトシークエンシングのいずれの 手法から得られたデータからも系統樹を作成することが可能である。しかし，ここでは， 煩雑さを避けるためダイレクトシークエンシングによって得られた塩基配列デー夕を使用 することを前提とする.

\section{1) 系統推定法}

得られた塩基配列データは専用のプログラム（DNASISなど）を用いてギャップの挿入 などの处理を行った上で系統推定に利用される．鳥類の系統推定法として良く使用される のは近隣結合法 (NJ 法 : neighbor-joining method), 最大節約法 (MP 法 : maximum parsimony method), 最尤法 (ML 法: maximum likelihood method) の3つである. それぞれ，系統推定の原理が異なり利点・欠点がある，この点については上島 (1996)， 長谷川・岸野 (1996), Swofford et al. (1996) に詳しい解説があるのでここでは詳細を 
省くが，各手法の特徴を十分に把握した上で使用することが望ましい，

最近は, 複数の DNA の領域（例えば Cyt.b 領域と Control 領域の両方の塩基配列）の データを総合評価するのが容易で，進化速度の分類群による不一致，多重置換などが存在 する条件下でる正しい系統関係を構築できる可能性が高い，などの長所から最尤法が使用 されることが多くなっている、ただし，どれかひとつの手法のみを使って系統樹を作成し ている研究は，現在では希であり，近隣結合法，最大節約法，最尤法のうちいずれか2つ， ちしくは全ての原理を用いて系統樹を作成し，各系統樹を比較することによって系統関係 を論議している研究が，少なくとも鳥類では主流である.

実際にこれらの系統推定には，コンピューターソフトウェアを利用することになる，使 用する系統推定法やオペレーションシステムにより多数のソフトゥェアが出回っている. 分子データを用いた系統推定に使用できるソフトウェア（名称, 使用可能な手法, 使用可 能なオペレーションシステム，入手先）の一筧表はSwofford et al. (1996) に揭載され ている．また，日本語での紹介は長谷川・岸野（1996）に掲載されている．これらのソフ トゥェアのうち，鳥類の分子系統学的研究で頻繁に使用されているのは，愊広い手法が使 用できる PHYLIP (Felsenstein 1996) と最節約法を中心に使用できるPAUP (Swofford 1993）の 2 ソフトである.

\section{2 ）外群の使用}

系統樹には，共通祖先からの分貱点（根=root）が示されているあのと（有根系統樹） と示されていないもの（無根系統樹，ネットワーク）がある，上記 3 手法では基本的に無 根系統樹を作成するようになっている，しかし，無根系統樹だけでは系統関係が判らない ことが多いので，正確な系統関係を把握するには，系統樹に根を付けることが必要である. 根を付けるために用いられる一般的な手法は，研究対象となる分類群（队群 ingroup）以 外の分類群（外群 outgroup）のデー夕を利用する外群付根法 (outgroup rooting) であ る.これは，外群の情報（塩基配列デー夕）を基に外群と内群を分けている玟の上に根を 付ける方法だが，内群と系統関係が離れてすぎている外群を用いた場合，譟った系統樹を 構築する場合がある，このため信頼性の高い系統樹を構築するためには，外群の選択にあ たって，(1)できる限り内群と系統学的に近縁な分類群を用いる．(2)できるだけ多くの外群 を用いることが必要である（上島 1996）．実際には系統推定ソフトウェアで系統樹を作成 する際に，対象とする分類群の塩基配列デー夕と共に外群の塩基配列データを入力するこ とで根をつける事ができる。

\section{3) 重みづけの問題}

系統樹を作成する際，トランジッション（TS）とトランスバージョン（TV）の起こり 易さが異なることに基づいて重みづけする場合がある. 鳥類のCyt.b領域ではTS:TV $=20$ : 1 (Edwards et al. 1991), $9: 1$ (Hackett 1995), 5:1 (Helbig et al. 1995) などが 使用されているが，今のところ確定された值はなく，全く重みづけを行わない場合すある. 多くの場合, 複数の重みつけけ值を用いて複数の系統樹を推定し, 各系統樹の信頼性を検討 した上で考察を加えている. 


\section{4) 多重置換の問題}

系統樹の推定の際, しばしば問題になるのが一度置換した塩基が再び置換を起こす多重 置換である．場合によっては再び元の塩基に戻ってしまうことも考えられる．特にコドン の 3 番目の塩基は進化速度が早く, Cyt.b 領域において約 $10 \%$ の塩基配列の相違が存在す る種間では, コドンの 3 番目の塩基の変異は飽和していることが知られている (Edwards et al. 1991, Hackett 1995).このため, 分化程度の大きい分類群間では誤った系統樹を 推定する可能性が出てくる. 分化程度の大きい分類群間の系統推定には, 進化速度のより 遅い領域を使用することで多重置換の影響をある程度排除することが可能である. 実際に は, Cyt.b 領域で約10\%以上の相遣のある分類群の比較には進化速度の遅い 12SrRNA 領 域の解析を併用することで，ある程度系統推定の誤りを防ぐことができると思われる.

\section{5) データバンクの使用}

これまでに解析された鳥類の塩基配列データは，ほとんどの場合データベースに登録さ れており，文中にデータの受入番号（accession number）を明記すれば引用す可能であ る. また，自らの分析した塩基配列データを登録することもできる．日本では，国立遗伝 学研究所生命情報センターが日本 DNA データバンク（略称 DDBJ）を運営している．ま た，海外のデータベース（米国の NCBI 及び NCGR，欧州の EBI）と共同で国際DNA デー タベース (DDBJ/EMBL/GenBank International Nucleotide Sequence Database) を 共同構築し運営しているので, 海外の研究例についても検索が可能である. データベース の利用法については国立遣伝学研究所生命情報センターに直接問い合わせることも可能で あるが，詳しい解説書む市販されている（高木・金久 1996).

\section{6 ）系統樹の信頼性の検討（ブーッストラップ法）}

系統樹の中の特定の枝（分岐）の信頼性を統計学的に評価する方法としては, ジャック ナイフ法 (jackknife method) やブーッストラップ法 (bootstrap method) などが知ら れている. 現在最も頻繁に使用されている方法は, ブーッストラップ法である.この方法 は，系統樹を作成するのに使用した塩基配列データから無作為に塩基データ（1bp）を抜 き出すことをくり返して，もとの塩基配列データの長さと同じ長さの疑似塩基配列データ を作成し，それを使用して系統樹（ブーッストラップ系統樹）を作成する．ここまでの作 業を 1 回として, 同様の作業を多数回（現在では通常1,000回以上）くり返す．この結果 得られた多数のブーッストラップ系統樹のうち，むとの塩基配列データから得られた系統 樹の特定の枝が再現されたものの頻度（\%) を調べるものである（上島 1996），疑似デー 夕を作成する際の抽出は, 重複を䛨しているので, ある部分は複数回抽出され，他のある 部分は全く抽出されないということが起こりうる．得られた頻度はブーッストラップ確率 (bootstrap probability=BP) と呼ばれる. BPが100\%に近いほど，その枝の信頼性は高 いと考えられる. BP は各枝（分岐）ごとに計算されるため系統樹のそれぞれの枝に BP が表示され，枝ごとの信頼度を評価することができる，従って，構築された系統樹の内， ある特定部分だけが信頼性が高く，他はあまり支持されないというケースは往々にして起 こりうる.

BP は, 得られた樹形がその分類群の系統関係を正しく示しているか否かを表わす値と 
受け取られることが多いが，実際には使用した塩基配列データの範囲内に特定の枝 (分岐) を支持するデータがぞの程度含まれているかを大まかに示した值にすぎない（上島 1996）. 使用したデータに何らかの偏りがあった場合や，データの量が少ない場合など，高い BP の值が得られたとしてあ実際には間違った系統関係を示している場合るある. 系統樹の基 になったデータの質を考慮することなしにBP の值の高低のみで系統樹の信頼性を評価す るのは非常に危険である.

塩基置換は確率過程である以上，ある遗伝子の塩基配列から推定した系統関係は当然な がら誤差を含んでおり，その分子系統樹が100\%正しいことはあり得ない（上島 1996）. また，系統樹作成法やその前提となる進化モデルにしても完成されたすのではなく，様々 な問題が依然として多く残されており，今後多くの点で改善が予想される. 従って, 現時 点で作成された系統樹をそのまま鴝吞みにするのではなく，個々の系統樹の信頼性を冷静 に判断する必要がある．改善された系統推定法を使用した場合，これまで提出されていた 分子系統樹の樹形が変更になることも起こりうると思われる. しかし，解析された個々の 塩基配列データそのものは信頼性が高く，系統樹作成法が改善されれば同じデータを用い て, よりよい分子系統樹を構築することが可能である.

7 ）分子系統と他の形質から推定された系統の不一致

分子データから推定された系統樹と形態や生態的形質から推定された系統樹が一致しな い場合どちらを信用すればよいのかといった疑問がしばしば呈される：塩基配列などの分 子データ, 特に mtDNA のみの塩基配列デー夕を使用した場合の問題点や系統樹推定の 原理や方法についての不確定要䒺は今のところ数多く存在しているため, 現在示されてい る系統樹が正確であると断定はできない，また，前述した様に得られる系統樹の全ての枝 が100\%正しいことはあり得ない.

しかし，現在得られる情報の中で mtDNAの塩基配列データは最も有効な系統推定の 道具であることは間違いなく，いくつかの問題点を除くことができれば, 形態や生態に比 べ系統を推定する能力は非常に高いと思われる，従って，問題点をクリアーした信頼性の 高い分子データの系統之形態形質や生態形質から推定した系統が一致しない場合, 分子デー 夕から得られた系統の方が対象とした分類群の分化の順番と分化の時間的な長さを正しく 示している場合が多いと考えられる．ただし，分子データから推定された系統樹は，あく まで対象とした遗伝子領域（例えばCyt.b 領域）の系統を示しているのであって，この遺 伝子系統樹を実際の分類群の系統を示す系統樹であるとみなすに，遗伝子の系統関係と 分類群の系統関係が同形であるとの仮定が必要になる（三中 1997）遗伝子系統樹を基に 分類群の系統を論じる場合には，この点に注意することを忘れてはならない．

\section{研究事例}

1990年代にはDNAを利用した多くの系統学的研究が行われ, 対象となった分類群む多 岐にわたる（Table 2)。最近の研究例については石田 (1996), Baker \& Marshall (1997), Houde et al. (1997), Moor \& DeFilippis (1997) によって総説がなされてい る.ここでは DNA の塩基配列データから鳥類の系統解析を行った研究の中から，日本に 
Table 2. Example of avian molecular phylogenetic studies, 1990 to 1998.

\begin{tabular}{|c|c|c|c|}
\hline $\begin{array}{c}\text { Taxon } \\
\text { 対象とする分類群 }\end{array}$ & $\begin{array}{l}\text { Method } \\
\text { 1) 解析手法 }\end{array}$ & $\begin{array}{c}\text { Gene(bp) } \\
\text { 2) 領域(解析壏基数) }\end{array}$ & $\begin{array}{c}\text { References } \\
\text { 文献 }\end{array}$ \\
\hline $\begin{array}{l}\text { Struthio camelus ssp. } \\
\text { ダチョウの亜種 }\end{array}$ & RFLP & & $\begin{array}{l}\text { Freitag \& Robinson } \\
(1993)\end{array}$ \\
\hline $\begin{array}{l}\text { Procellariiformes, Sphenisciformes } \\
\text { ミズナギドリ目, ペンギン目 }\end{array}$ & Seq, Allo & 12SrRNA（381bp） & $\begin{array}{l}\text { Paterson et al. } \\
\text { (1995) }\end{array}$ \\
\hline $\begin{array}{l}\text { Diomedeidae } \\
\text { アホゥドリ科 }\end{array}$ & Seq & Cyt.b (1143bp) & Nunn et al. (1996) \\
\hline $\begin{array}{l}\text { Pterodroma heraldica } \\
\text { シロハラミスナギドリ属の } 1 \text { 種 }\end{array}$ & Seq & Cyt.b (307bp) & $\begin{array}{l}\text { Brooke \& Rowe } \\
\text { (1996) }\end{array}$ \\
\hline $\begin{array}{l}\text { Puffinus lherminieri, } P \text {. assimilis } \\
\text { ヒメミズナキドリ，セグロミスナギトリ }\end{array}$ & Seq & Cyt.b (307bp) & Austin (1996) \\
\hline $\begin{array}{l}\text { Psudebulweria, Bulweria } \\
\text { アナドリ属他 }\end{array}$ & Seq & Cyt.b (496bp) & $\begin{array}{l}\text { Bretagnolle et al. } \\
\text { (1998) }\end{array}$ \\
\hline $\begin{array}{l}\text { Oceanodroma } \\
\text { ウミツバメ属 }\end{array}$ & Seq & Cyt.b (302bp) & $\begin{array}{l}\text { Dawson et al. } \\
\text { (1997) }\end{array}$ \\
\hline $\begin{array}{l}\text { Zebrilus undulatus, Tigriornis leucolophus } \\
\text { コビトトラフサギ,アフリカトラフサギ }\end{array}$ & Hybrid & & $\begin{array}{l}\text { Sheldon et al. } \\
\text { (1995) }\end{array}$ \\
\hline $\begin{array}{l}\text { Aquila } \\
\text { イヌワシ属 }\end{array}$ & Seq & Cyt.b (1026bp) & $\begin{array}{l}\text { Seibold et al. } \\
\text { (1996) }\end{array}$ \\
\hline $\begin{array}{l}\text { Branta canadensis, B. sandvicensis } \\
\text { カナダガン, ハワイガン }\end{array}$ & RFLP & & Quinn et al. (1991) \\
\hline $\begin{array}{l}\text { Anas, Mergus } \\
\text { マガモ属, アイサ属 }\end{array}$ & RFLP & & Tuohy et al. (1992) \\
\hline $\begin{array}{l}\text { Anas platyrhynchos, A. superciliosa } \\
\text { マガモ, マミジロカルガモ }\end{array}$ & RFLP & & $\begin{array}{l}\text { Rhymer et al. } \\
\text { (1994) }\end{array}$ \\
\hline $\begin{array}{l}\text { Tympanuchus } \\
\text { ソウゲンライチョウ属 }\end{array}$ & RFLP, Allo & & $\begin{array}{l}\text { Ellsworth et al. } \\
\text { (1994) }\end{array}$ \\
\hline $\begin{array}{l}\text { Tetraoninae } \\
\text { ライチョウ亜科 }\end{array}$ & RFLP & & $\begin{array}{l}\text { Ellsworth et al. } \\
\text { (1995) }\end{array}$ \\
\hline $\begin{array}{l}\text { Tetraoninae } \\
\text { ライチョウ亜科 }\end{array}$ & Seq & Cyt.b (609bp) & $\begin{array}{l}\text { Ellsworth et al. } \\
\text { (1996) }\end{array}$ \\
\hline $\begin{array}{l}\text { Callipepla } \\
\text { ウロコウズラ属 }\end{array}$ & Seq & Cyt.b, ND2 (1040bp) & $\begin{array}{l}\text { Zink \& Blackwell } \\
\text { (1998) }\end{array}$ \\
\hline $\begin{array}{l}\text { Francolinus } \\
\text { シャコ属 }\end{array}$ & RFLP & & Crowe et al. (1992) \\
\hline $\begin{array}{l}\text { Gruidae } \\
\text { ッル科 }\end{array}$ & Seq & Cyt.b (1042bp) & $\begin{array}{l}\text { Krajewski \& Fetzner, } \\
\text { Jr. (1994) }\end{array}$ \\
\hline $\begin{array}{l}\text { Gurs antigone } \\
\text { オオヅル }\end{array}$ & Seq & $\begin{array}{l}\text { Cyt.b, tRNAThr } \\
\text { tRNAPro, (1304bp) }\end{array}$ & $\begin{array}{l}\text { Krajewski \& Wood } \\
\text { (1995) }\end{array}$ \\
\hline $\begin{array}{l}\text { Gurs antigone ssp. } \\
\text { オオヅルの亜種 }\end{array}$ & Seq & $\begin{array}{l}\text { Cyt.b, tRNAThr } \\
\text { tRNAPro, ND6(1831bp) }\end{array}$ & $\begin{array}{l}\text { Wood \& Krajewski } \\
\text { (1996) }\end{array}$ \\
\hline $\begin{array}{l}\text { Rhynochetos jubatus } \\
\text { カグー }\end{array}$ & Seq & 12SrRNA (400bp) & $\begin{array}{l}\text { Kakizawa et al. } \\
\text { (1996) }\end{array}$ \\
\hline $\begin{array}{l}\text { Phalaropus } \\
\text { ヒレアシシギ属 }\end{array}$ & RFLP & & $\begin{array}{l}\text { Dittmann \& Zink } \\
\text { (1991) }\end{array}$ \\
\hline $\begin{array}{l}\text { Calidris alpina, Arenaria interpres } \\
\text { 八マシキ, キョウショシキ }\end{array}$ & Seq & Control (1000bp) & $\begin{array}{l}\text { Wenink et al. } \\
\text { (1994) }\end{array}$ \\
\hline $\begin{array}{l}\text { Calidris alpina } \\
\text { ハマシギ }\end{array}$ & Seq & Control (608bp) & $\begin{array}{l}\text { Wenink \& Baker } \\
\text { (1996) }\end{array}$ \\
\hline $\begin{array}{l}\text { Calidris paramelanotos } \\
\text { Cox's Sandpiper }\end{array}$ & Seq, Allo & Cyt.b (288bp) & $\begin{array}{l}\text { Christidis et al. } \\
\text { (1996a) }\end{array}$ \\
\hline $\begin{array}{l}\text { Brachyramphus perdix } \\
\text { マダラウミススメ属の } 1 \text { 種 }\end{array}$ & Seq, Allo & Cyt.b (1045bp) & $\begin{array}{l}\text { Friesen et al. } \\
\text { (1996) }\end{array}$ \\
\hline
\end{tabular}


Table 2. continued

\begin{tabular}{|c|c|c|c|}
\hline $\begin{array}{c}\text { Taxon } \\
\text { 対象とする分類群 } \\
\end{array}$ & $\begin{array}{l}\text { Method } \\
\text { 1) 解析手法 }\end{array}$ & $\begin{array}{c}\text { Gene(bp) } \\
\text { 2) 領域(解析壏基数) }\end{array}$ & $\begin{array}{l}\text { References } \\
\text { 文献 }\end{array}$ \\
\hline $\begin{array}{l}\text { Geopsittacus occidentalis, Pezoporus wallicus } \\
\text { ヒメフクロウインコ, キジインコ }\end{array}$ & Seq & Cyt.b (924bp) & $\begin{array}{l}\text { Leeton et al. } \\
\text { (1994) }\end{array}$ \\
\hline $\begin{array}{l}\text { Cuculus canorus } \\
\text { カッコウ }\end{array}$ & Seq & ND6 (474bp) & $\begin{array}{l}\text { Jones \& Gibbs } \\
\text { (1997) }\end{array}$ \\
\hline $\begin{array}{l}\text { Strigiformes } \\
\text { フクロウ目 }\end{array}$ & RFLP & & Li et al. (1998) \\
\hline $\begin{array}{l}\text { Mimizuku gurneyi } \\
\text { オニコノハズク }\end{array}$ & Seq & $\begin{array}{l}\text { 12SrRNA, COI } \\
(2140 \mathrm{bp})\end{array}$ & $\underset{(1997)}{\text { Miranda et al. }}$ \\
\hline $\begin{array}{l}\text { Trochilidae } \\
\text { ハチドリ科 }\end{array}$ & Hybrid & & $\begin{array}{l}\text { Bleiweiss et al. } \\
\text { (1994) }\end{array}$ \\
\hline $\begin{array}{l}\text { Anthracoceros } \\
\quad \text { カササギサイチョウ属 }\end{array}$ & Seq & Cyt.b (189bp) & $\begin{array}{l}\text { Srikwan \& Woodruff } \\
\text { (1998) }\end{array}$ \\
\hline $\begin{array}{c}\text { Capitonidae, Ramphastidae } \\
\text { ゴシキドリ科, オオハシ科 }\end{array}$ & Seq & Cyt.b (888bp) & $\begin{array}{l}\text { Lanyon \& Hall } \\
\text { (1994) }\end{array}$ \\
\hline $\begin{array}{l}\text { Sphyrapicus } \\
\text { シルスイキッッキ属 }\end{array}$ & Seq & Cyt.b (711bp) & $\begin{array}{l}\text { Cicero \& Johnson } \\
\text { (1995) }\end{array}$ \\
\hline $\begin{array}{l}\text { Leptopogon } \\
\text { ハシジソハェトリ属 }\end{array}$ & RFLP, Allo & & $\begin{array}{l}\text { Bates \& Zink } \\
\text { (1994) }\end{array}$ \\
\hline $\begin{array}{c}\text { Empidonax traillii, } E \text {, alnorum } \\
\text { メジロハエトリ, キタメジロハエトリ }\end{array}$ & RFLP & & Winker (1994) \\
\hline $\begin{array}{l}\text { Certhilauda albescens } \\
\text { ウスイロハシボソヒバリ }\end{array}$ & Seq & Cyt.b (495bp) & Ryan et al. (1998) \\
\hline$\underset{\text { ツirundinidae }}{\text { Hix十 }}$ & Hybrid & & $\begin{array}{l}\text { Sheldon \& Winkler } \\
\text { (1993) }\end{array}$ \\
\hline $\begin{array}{l}\text { Hirundinidae } \\
\text { ツバメ科 }\end{array}$ & Hybrid & & $\begin{array}{l}\text { Winker \& Sheldon } \\
\text { (1993) }\end{array}$ \\
\hline $\begin{array}{l}\text { Anthus } \\
\text { タヒバリ属 }\end{array}$ & Seq & Cyt.b (1041bp) & $\begin{array}{l}\text { Arctander et al. } \\
(1996)\end{array}$ \\
\hline $\begin{array}{l}\text { Motacillidae } \\
\text { セキレイ科 }\end{array}$ & Seq & Cyt.b (1035bp) & $\begin{array}{l}\text { Voelker \& Edwards } \\
\text { (1998) }\end{array}$ \\
\hline $\begin{array}{l}\text { Laniarius } \\
\text { ヤブモズ属 }\end{array}$ & Seq & Cyt.b (295bp) & Smith et al. (1991) \\
\hline $\begin{array}{l}\text { Toxostoma lecontei } \\
\text { サボテンムジッグミモドキ }\end{array}$ & Seq & Cyt.b, ND6 (619bp) & Zink et al. (1997) \\
\hline $\begin{array}{l}\text { Muscicapidae } \\
\text { 七タキ科他 }\end{array}$ & Seq & $\begin{array}{l}\text { Cyt.b, 18SrRNA } \\
\text { (936bp) }\end{array}$ & $\begin{array}{l}\text { Chikuni et al. } \\
\text { (1996) }\end{array}$ \\
\hline $\begin{array}{l}\text { Pomatostomus } \\
\text { オーストラリアマルハシ属 }\end{array}$ & Seq & $\begin{array}{l}\text { Cyt.b, 12SrRNA } \\
\text { (633bp) }\end{array}$ & $\begin{array}{l}\text { Edwards \& Wilson } \\
(1990)\end{array}$ \\
\hline $\begin{array}{l}\text { Pomatostomus temporalis } \\
\text { オーストラリアマルハシ }\end{array}$ & Seq & Control $(400 \mathrm{bp})$ & Edwards (1993) \\
\hline $\begin{array}{l}\text { Acrocephalus } \\
\quad \exists シ キ リ \text { 属 }\end{array}$ & Seq & Cyt.b (1068bp) & Leisler et al. (1997) \\
\hline $\begin{array}{l}\text { Phylloscopus } \\
\text { メボソムシクイ属 }\end{array}$ & Seq & Cyt.b (910bp) & $\begin{array}{l}\text { Richman \& Price } \\
\text { (1992) }\end{array}$ \\
\hline $\begin{array}{l}\text { Phylloscopus bonelli, } P \text {. nitidus } \\
\text { ボネリームシクイ、ミドリムシクイ }\end{array}$ & Seq & Cyt.b (1038bp) & $\begin{array}{l}\text { Helbig et al. } \\
\text { (1995) }\end{array}$ \\
\hline $\begin{array}{l}\text { Phylloscopus collybita } \\
\text { チフチャフ }\end{array}$ & Seq & Cyt.b (1041bp) & $\begin{array}{l}\text { Helbig et al. } \\
\text { (1996) }\end{array}$ \\
\hline 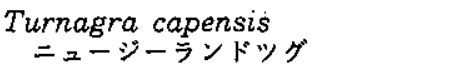 & Seq & Cyt.b (924bp) & $\begin{array}{l}\text { Christidis et al. } \\
\text { (1996b) }\end{array}$ \\
\hline $\begin{array}{l}\text { Parus } \\
\text { シジュウカラ属 }\end{array}$ & RFLP & & Ball \& Avise (1992) \\
\hline
\end{tabular}


Table 2. continued

\begin{tabular}{|c|c|c|c|}
\hline $\begin{array}{c}\text { Taxon } \\
\text { 対象とする分類群 }\end{array}$ & $\begin{array}{l}\text { Method } \\
\text { 1) 解析手法 }\end{array}$ & $\begin{array}{c}\text { Gene (bp) } \\
\text { 2) 領域(解析塩基数) } \\
\end{array}$ & $\begin{array}{l}\text { References } \\
\text { 文献 }\end{array}$ \\
\hline $\begin{array}{l}\text { Parus } \\
\text { シジュウカラ属 }\end{array}$ & RFLP & & $\begin{array}{l}\text { Gill \& Slikas } \\
(1992)\end{array}$ \\
\hline $\begin{array}{l}\text { Parus } \\
\text { ジショゥカラ属 }\end{array}$ & Hybrid & & $\begin{array}{l}\text { Sheldon et al. } \\
\text { (1992) }\end{array}$ \\
\hline $\begin{array}{l}\text { Parus } \\
\text { シシュゥカラ属 }\end{array}$ & RFLP & & Gill et al. (1993) \\
\hline $\begin{array}{l}\text { Parus } \\
\text { シジュウカラ属 }\end{array}$ & Seq & Cyt.b (439bp) & Kvist et al. (1996) \\
\hline $\begin{array}{l}\text { Paridae } \\
\text { シジュゥカラ科 }\end{array}$ & Hybrid & & $\begin{array}{l}\text { Sheldon \& Gill } \\
\text { (1996) }\end{array}$ \\
\hline $\begin{array}{l}\text { Paridae } \\
\text { シジュウカラ科 }\end{array}$ & Hybrid & & Slikas et al. (1996) \\
\hline $\begin{array}{l}\text { Sitta } \\
\text { ゴシュゥカカラ属 }\end{array}$ & Seq & Cyt.b (491bp) & Pasquet (1998) \\
\hline $\begin{array}{l}\text { Zosterops luteus, Z. lateralis } \\
\text { キバラメジロ, ハイムネメジロ }\end{array}$ & RFLP & & $\begin{array}{l}\text { Degnan \& Moritz } \\
\text { (1992) }\end{array}$ \\
\hline $\begin{array}{l}\text { Apalopteron familiare } \\
\text { メグロ }\end{array}$ & Seq & 12SrRNA（401bp） & $\begin{array}{l}\text { Springer et al. } \\
\text { (1995) }\end{array}$ \\
\hline $\begin{array}{l}\text { Passerella iliaca, Melospiza melodia } \\
\text { ゴマフスズメ, ウタスズメ }\end{array}$ & RFLP & & Zink (1991) \\
\hline $\begin{array}{l}\text { Passerella iliaca } \\
\text { I゙マフススメ }\end{array}$ & RFLP & & Zink (1994) \\
\hline $\begin{array}{l}\text { Melospiza melodia } \\
\text { ウタスズ }\end{array}$ & RFLP & & $\begin{array}{l}\text { Hare \& Shields } \\
(1992)\end{array}$ \\
\hline $\begin{array}{l}\text { Melospiza georgiana } \\
\text { ヌマウタススメ }\end{array}$ & Seq & $\begin{array}{l}\text { Control, COII } \\
\text { tRNAlys, ATP8 (641bp) }\end{array}$ & $\begin{array}{l}\text { Greenberg et al. } \\
\text { (1998) }\end{array}$ \\
\hline $\begin{array}{l}\text { Zonotrichia } \\
\quad \text { ミヤマシト属 }\end{array}$ & RFLP & & Zink et al. (1991a) \\
\hline $\begin{array}{l}\text { Zonotrichia capensis } \\
\text { アカエリシトト }\end{array}$ & RFLP & & $\begin{array}{l}\text { Lougheed \& Handford } \\
\text { (1993) }\end{array}$ \\
\hline $\begin{array}{l}\text { Passerculus sandwichensis } \\
\text { クサチヒメドリ }\end{array}$ & RFLP & & Zink et al. (1991c) \\
\hline $\begin{array}{l}\text { Ammodramus caudacutus } \\
\text { トゲオヒメドリ }\end{array}$ & RFLP & & $\begin{array}{l}\text { Rising \& Avise } \\
(1993)\end{array}$ \\
\hline $\begin{array}{l}\text { Spizella } \\
\quad \text { ヒメドリ属 }\end{array}$ & RFLP & & $\begin{array}{l}\text { Zink \& Dittmann } \\
\text { (1993) }\end{array}$ \\
\hline $\begin{array}{l}\text { Pipilo, Spizella } \\
\text { トウヒチョウ属，ヒメドリ属 }\end{array}$ & Seq, RFLP & Cyt.b (433bp) & Dodge et al. (1995) \\
\hline $\begin{array}{l}\text { Piranga } \\
\quad \text { フウキンチョウ属 }\end{array}$ & Seq & Cyt.b (1045bp) & Burns (1998) \\
\hline $\begin{array}{c}\text { Diglossa baritula } \\
\text { ハナナサシミッドリ }\end{array}$ & Seq, Allo & Cyt.b (307bp) & Hackett (1995) \\
\hline $\begin{array}{l}\text { Hemignathus } \\
\quad \text { エミハシハワイミンイイ属 }\end{array}$ & RFLP & & $\begin{array}{l}\text { Tarr \& Fleischer } \\
(1993)\end{array}$ \\
\hline $\begin{array}{l}\text { Vireonidae } \\
\text { モズモドキ科 }\end{array}$ & Seq & Cyt.b (273bp) & Murray et al. (1994) \\
\hline $\begin{array}{l}\text { Quiscalus quiscula } \\
\text { オオクロムクドリモドキ }\end{array}$ & RFLP & & Zink et al. (1991b) \\
\hline $\begin{array}{l}\text { Carduelis flammea, C. hornemanni } \\
\text { ベニヒワ,コベニヒワ }\end{array}$ & RFLP & & Seutin et al. (1995) \\
\hline $\begin{array}{l}\text { Corvidae } \\
\text { カラス科 }\end{array}$ & Seq & Cyt.b (1143bp) & $\begin{array}{l}\text { Helm-Bychowski \& } \\
\text { Cracraft (1993) }\end{array}$ \\
\hline
\end{tabular}


Table 2. continued

\begin{tabular}{|c|c|c|c|}
\hline $\begin{array}{c}\text { Taxon } \\
\text { 対象とする分類群 }\end{array}$ & $\begin{array}{l}\text { Method } \\
\text { 1) 解析手法 }\end{array}$ & $\begin{array}{c}\text { Gene (bp) } \\
\text { 2) 領域(解析塩基数) }\end{array}$ & $\begin{array}{l}\text { References } \\
\text { 文献 }\end{array}$ \\
\hline $\begin{array}{l}\text { Corvidae } \\
\text { カラス科 (カケス類) }\end{array}$ & Seq & Cyt.b (1143bp) & $\begin{array}{l}\text { Monteros \& Cracr } \\
\text { (1997) }\end{array}$ \\
\hline $\begin{array}{l}\text { Many species } \\
\text { 旧大陸と新大陸両方に分布する種 }\end{array}$ & RFLP & & Zink et al. (1995) \\
\hline \multicolumn{4}{|c|}{ 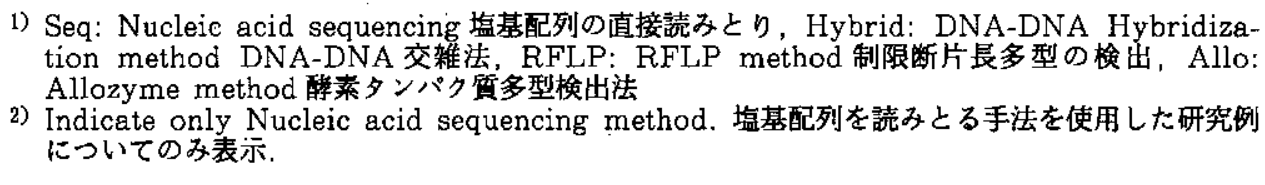 } \\
\hline
\end{tabular}

生息する種の系統推定と分類に関する成果のいくつかを紹介する.

\section{1）アホウドリ類}

Nunn et al. (1996) によって, 現生のアホウドリ類全14種の系統解析が Cyt.b 領域の 全塩基配列1,143bpを用いて行われ，アホウドリDiomedea albatrus の最近縁種は, 太平 洋を挟んだ反対側で繁殖するガラパゴスアホウドリD. irrorataであることが示された. また, この研究からクロアシアホウドリD. nigripes とコアホウドリ D. immutabilis が 近縁であること，これら北半球（ガラパゴスアホゥドリは赤道直下）で繁殖するアホウド リ類 4 種が比較的近縁な 1 つのグループを形成することなどあ明らかになった. Nunn et al. (1996) は，この研究に基づいてアホゥドリ，ガラパゴスアホウドリ，コアホウドリ， クロアシアホウドリの 4 種をDiomedea 属から分離して Phoebastria 属とする新分類体系 を提唱した。この分類体系は American Ornithologists' Union（1997）によって採用さ れているが, 日本では今のところ採用されていない（日本鳥学会目録編集委員会 1997）.

\section{2) タンチョウ}

Krajewski \& Fetzner, Jr. (1994) によって, 現生のッル類全14種の系統解析が Cyt.b 領域の塩基配列1,142bpを用いて行われ，タンチョウGrus japonensisが，遺伝的にクロ ヅル G. grus, オグロヅル G. nigricollis, ナベッ゙ル G. monacha, アメリカシロッル $G$. americana の 4 種と比較的近縁な 1 つのグループを形成するすのの, これら 5 種の中では 最す早期に分化して抢り, 現生ッル類の中に 遗伝的にごく近縁な種は存在しないことな どが明らかにされた.

\section{3）アカハラ・シロハラ・マミチャジナイ}

日本及びその周辺に繁殖分布するシロハラTurdus pallidus, マミチャジナイ T. obscurus, アカハラT. chrysolaus の 3 種のッグミ類は, 形態的に類似点が多いこと, 分 布が側所的であることなどから比較的近年分化した近縁な種（上種superspecies）である と考えられていた（日本鳥学会 1974, Morioka 1982）. Chikuni et al. (1996) の塩基 配列デー夕 (Cyt.b 領域の部分塩基配列 $646 \mathrm{bp}$ )を用いた系統解析からも，これら 3 種の 分化の程度が低く，遗伝的な面からも近縁なひとつのグループを形成することが確かめら 
れた（各種間の相違は分析された配列全体の約 $3.0 \%$ 程度，同属のッグミ T.naumanniや クロッグミT.cardis とは $6 \%$ 以上の相違がある).

\section{4) オオヨシキリ}

日本です繁殖するオオョシキリは, 形態の研究に基づきニシオオヨシキリ Acrocephalus arundinaceus $の 1$ 亜種 $A$. a. orientalis として扱われることが多いが（日本鳥学会 1974, 日本鳥学会目録編集委員会 1997), 独立種 A.orientalis とする考えもあり見解は統一され ていない (Shirihai et al. 1995). Leisler et al. (1997) によるCyt.b 領域の部分塩基配 列1,068bpを用いた系統解析ではオオヨシキリはチュウヨシキリA. stentoreus と遺伝的 に近縁（闭者の相違は平均 $4.2 \%$ ）で，ニシオオョシキリとはやや類縁が遠い（平均 $6.3 \%$ の相違）ことが明らかになった。

\section{5) イイジマムシクイ・センダイムシクイ}

日本固有種であるイイジマムシクイPhylloscopus ijimae の類縁については，過去にお ける研究からセンダイムシクイP. coronatusに近縁であるとする説 (Ticehurst 1938) とエゾムシクイP. tenellipesに近縁とする説が存在した (Williamson 1976). Cyt.b 領 域の部分塩基配列 $910 \mathrm{bp}$ の分析から得られた系統樹は，イイジムシクイがセンダイムシ クイに近縁であること（7.9\%の相違），及びェゾムシクイがこれら 2 種とは異なる系統に 属することを示した（Richman \& Price 1992）。 また, センダイムシクイは形態的研究 からヒマラヤに隔離分布する二シセンダイムシクイ P. occipitalisの 1 亜種 P. o. coronatus として扱われる場合が多かった（日本鳥学会 1974）。しかし, 塩基配列データはセンダイ ムシクイとニシセンダイムシクイが別系統に属し，分化程度も比較的大きいこと $(11.6 \%$ の相違)を示した，日本であ現在はセンダイムシクイと二シセンダイムシクイを別種とす る分類体系を採用している（日本鳥学会目録編集委員会 1997）.

\section{6) メグロ}

小笠原諸島に生息するメグロ Apalopteron familiare は, 研究者間で分類学的見解が 一致しない種であった。これまで形態に基づきヒョドリ科，メジロ科，チメドリ科，ミッ スイ科に分類されたことがあり，現在はミッスイ科の 1 属 1 種として分類されている (Deignan 1958, 日本鳥学会 1974). Springer et al. (1995) は, 12SrRNA 領域の部分 塩基配列 $401 \mathrm{bp}$ 用いてメグロの系統解析を行い,メグロが遗伝的には，同じく 1 属 1 種 のオウゴンミッスイ Cleptornis marchei に近縁で, この 2 属がミッスイ科よりもメジロ 科に近縁であることを明らかにした。 しかし，分子系統解析に用いた分類群が十分でない ことと，形態形質など他形質の検討が十分でないことを理由にメグロをメジロ科に含む分 類体系昍日本では今のところ採用されていない（日本鳥学会目録編集委員会 1997).

\section{日本における研究課題}

日本及びその周辺においては, 分子系統学的手法を導入して研究にあたるべき研究課題 が, 未だ大量に存在している、この点については1987年に開催された日本鳥学会の津戸基 
金によるシンポジゥム「アジア・太平洋地域における鳥類の進化・生態学と DNA 多型利 用の可能性」の中で上田恵介氏が総説している（上田 1997）. 重なる部分む多いがいくつ かの課題を示しておく．この中にはすでに分子系統学的研究が着手されている分類群もあ るが, 少なくとも論文として発表されたすのはない，また，ここにあげた分類群について は, 塩基配列が解析されていないのみではなく, 形態, 行動, 生態など各方面からの情報 が不足している場合が多く、今後各方面からの研究を進める必要がある.

\section{1）日本固有種の系統関係}

日本固有種の中には，系統関係が明らかになっていない種が多い，その中には形態や行 動から類推された系統関係が複数提唱され，研究者間での見解が一致しない種す多い.

奄美大島のルリカケス Garrulus lidthiについては，ヒマラヤに隔離分布するインドカ ケス G. lanceolatus との共通祖先を持つ遗存種とする説と単に島に隔離されたカケス $G$. glandarius が特殊化したものであるという説がある（山階 1942b, Kuroda 1957, 森岡 1974, Madge \& Burn 1994, Higuchi et al. 1995).

セグロセキレイ Motacilla grandisについてもインドのオオハクセキレイ $M$. maderaspatensis と共通祖先を持つ遺存種説とハクセキレイ $M$. alba に近縁とする説の 両方がある (中村 1985, 1987, Higuchi \& Hirano 1989).

アカコッコTurdus celaenops はアカハラT. chrysolausに近縁とする説とミヤンマー に生息するムナグロアカハラT. dissimilis，むしくはタイワンッグミT. poliocephalus のボルネオ産亜種 T. p. seebhomi と近縁な遗存種とする説の両方が提案されていて系統 的な位置が定まっていない（山階 1942, 藤村 1948, 日本鳥学会 1974, Kawaji et al. 1989, 森岡 1990).

ノグチゲラ Sapheopipo noguchii の近縁種や系統関係についても古くからアカゲラ Dendrocopos属むしくはアオゲラPicus 属との類縁が示唆されてきた（山階 1941，1955）. 近年においては，エビチャゲラ Blythipicus 属及びタケゲラ Gecinulus 属に近縁とする説 (Short 1973a,b)，オオアカゲラ Dendrocopos leucotosから直接分化したとする説 (Goodwin 1968), ヤマゲラ Picus canus との類縁関係を示唆する説（森岡 1974）など 様々な意見があり，明確な結論はでていない。

これら系統関係について複数の説が提唱されているすのの内のいくつかは, 収敛進化を 真の系統と見誤っている可能性が高い. DNA 解析を行うことで少なくとも収斂進化の影 製は取り除けるものと思われる. 真の系統関係を明らかにすることは, これら固有種の進 化及び固有化の歴史を考える上で不可欠である.

一方で, 類縁関係についてほぼ統一見解が示されている固有種もいくつか知られている. これらの種についてもDNA 分析を行うことで従来から提唱されていた類縁関係に強力な 裹付けが得られ, 分岐の順序や年代などの系統学的情報が得られる可能性が高い.

例えば，ヤマドリSyrmaticus soemmerringii は，台湾の高山に生息するミカドキジ S. mikado, カラヤマドリS. ellioti, オナガキジS. reevesii, ビルマカラヤマドリS. humiae との類縁性が指摘されている (Higuchi et al. 1995). ヤマドリについては国内 で顕著な亜種分化をあ生じており，これら亜種間の系統についても興味深い課題である.

アマミヤマシギScolopax mira とヤマシギS. rusticola は形態から近縁と考えられて 
いるが（森岡 1974），分化の程度など不明な点も多い，また，これら 2 種と東南アジアの 島懙性ヤマシギ類 3 種（ミナミヤマシギS. saturata，セレベスヤマシギS. celebensis, オビヤマシギS. rochussenii) 及び北米に広く分布するアメリカヤマシギS. minor との 系統関係あ不明である. ヤンバルクイナRallus okinawae はフィリピンなど東南アジア の島嶼に分布するムナオビクイナ R. torquatus との類縁性が形態面から指摘されている が具体的な研究は行われていない（Yamashina \& Mano 1981，黒田ら 1984).

ミゾゴイ Nycticorax goisagi はズグロミソゴイ N. melanolophus との, カラスバト Columba janthina はアカメカラスバトC. vitiensisなどとの類縁関係が示唆されている （黒田 1972）.

アカヒゲ Erithacus komadoriについてもコマドリE. ahahige, シマゴマE. sibilans など他のErithacus 属の種との系統関係が不明な上，亜種分類上の問題む解決されていな い (山階 1942b, Kawaji \& Higuchi 1989).

ノジョ Emberiza sulphurataの系統関係についてはアロザイムによる研究によってア オジE. spodocephalaに非常に近縁で次いでクロジE. variabilis に近縁であることが明 らかになっている (Watada et al. 1995). ただし, この点についてDNAを用いての追 試は今のところおこなわれていない。

2) $\exists$ ロッパの類似種との関係

ヨーロッパコマドリErithacus rubecula とコマドリE. akahige, ヨーロッパアオゲラ Picus viridis とアオゲラP. awokera，ヨーロッパカヤクグリPrunella modularis とカ ヤクグリP. rubida，オニミズナギドリCalonectris diomedea とオオミズナギドリC. leucomelasなど別種と考えられてはいるが形態的に良く似た種がヨーロッパと日本周辺 に隔離して分布している例は多い（Meinertzhagen 1951，黒田 1972）。しかし，これら が共通の祖先を持つ近縁種なのか，単に収斂して形態が類似しているのかについては未だ に明らかになっていない，また同属の他種も交えた系統関係については研究が進んでいな い.

オナガ Cyanopica cyana は， ヨーロッパのイベリア半島と日本を含む東アジア地域に 極端に隔離された分布域を持つが，形態的な類似から同種と考えられている (Meinertzhagen 1928，1951)。このような隔離された分布域を持つためにオナガは，新 生代第三紀起源の古い種と考えられることが多い（Udvardy 1969, 黒田 1972, 中村 1992). しかし、イベリア半島のオナガについては，人為的移入種である可能性む示唆さ れている (Goodwin 1986). 形態的には，亜種分化が認められることから人為的な移入 種である可能性は低いと思われるが，この点についての遣伝的側面からの考察は今のとこ ろ行われていない.

3）日本と中国大陸に隔離分布する種

日本国内以外には中国大陸に隔離された極めて局地的な繁殖分布域を持つ種がいくつか 知られている. 両分布域間の個体の交流が見在もあるのか否か，両者の分化程度など， DNA 解析を利用することで明らかになることあ多いと思われる。このような分布域を持 つ種としては，キビタキFicedula narcissina，クロッグミTurdus cardis，オオセッカ 
Locustella pryeri, コジュリン Emberiza yessoensis, トキNipponia nipponなどがあ げられ，このうちキビタキ，オオセッカ，コジュリンについては，大陸に分布する個体群 と日本国内に分布する個体群の間に形態的に亚種分化が認められている（クロッグミすか つては別巠種に分類されていたことがある). キビタキ，クロッグミにっいては近縁と推 測される種 (キビタキにはマミジロキビタキFicedula zanthopygia，クロッグミにはカ ラアカハラ Turdus hortulorum, ムナグロアカハラT. dissimilis） が側所的に分布して おりそれらとの系統関係す不明である．側所的な分布ではないるのの，コジュリンの分布 域の近刃にあ近緑と思われるシベリアジュリンE. pallasi, オオジュリンE. schoeniclus が分布しており，3者間の系統関係ははっきりしていない.

キビタキについては，国内にす亜種分化が認められており（南西諸島に分布するリュウ キュウキビタキ $F . n$. owstoni), 中国大陸の亜種 $F . n$. elisae 含めた 3 亜種間の系統 関係も明らかにはなっていない。

\section{4) 多様な亜種分化を示す種}

日本列島及びその周辺を中心とする比較的狭い分布域の中で顕著な亜種分化を示す種之 して, コゲラ Dendrocopos kizuki (13亜種), ヒヨドリHypsipetes amaurotis (14亜種), ウグイス Cettia diphone (12亜種)，ヤマガラ Parus varius (8 亜種), メジロZosterops japonicus ( 9 亜種)，カワラヒワ Carduelis sinica ( 6 带種)，なよ゙がある．これらの亜 種間系統や分化程度について研究することで带種分化のシステムを明らかにできる可能性 がある.

さらに, 広い分布域を持ち多くの亜種分化を示す種の中で, 日本に分布する亜種が重要 な分化を示している例として，キジ Phasianus colchicus (33亜種)，オオアカゲラ Dendrocopos leucotos (16覀種), トラッグミZoothera dauma (16亜種), メボソムシク 1 Phylloscopus borealis ( 7 重種), シジェウカラ Parus major (31重種), エナガ Aegithalos caudatus (19亜種), ウソPyrrhula pyrrhula (10正種)，カケス Garrulus glandarius (36亜種)，ハシブトガラスCorvus macrorhynchos（14亜種）などがあげら れる.これらの多くは日本国内に他地域とは形態的に大きく異なる固有亚種が生息してい る.これらは独立種か覀種かといった問題が論議されることも多いが，いずれも亜種間の 系統関係や遺伝的な分化程度すら明らかになっていない，例えば，トラッグミ Z d dauma の奄美大島固有亚種であるオオトラッグミZ．d. major は，艊りや尾羽の枚数などの独自 性を根拠に，近年独立種として扱うべきとの意見が盛んに提出されている（Ishihara 1986, 石田 1996, 奄美野鳥の会 1997). しかし, トラッグミZ. dauma は, 亜種により 尾羽の枚数（12枚の亜種と14枚の亜種が知られる）や体の大きさなどの形態形質や毄りな どが多様である．亜種オオトラッグミZ．d. majorに㡟りが類似し，尾羽の枚数も同じ12 枚の亜種も，ヒマラヤ産の基业種 $2 . d . d a u m a$ をはじめとしていくっか知られている. このため，亜種オオトラッグミの地位を明らかにするには，日本国内に分布する亜種のみ の比較検討だけでは不十分であり, 種内の亜種全体の系統や分化程度についての研究が必 要である. 分子系統学的アプローチは，このような種の研究には非常に適している．他に 同様の問題を抱える分類群としては，リュウキュウコノハズクOtus elegans, オオコノ ハズク Otus bakkamoena, シロガシラ Pycnonotus sinensis orii, リュウキュウサンショ 
ウクイ Pericrocotus divaricatus tegimae, ウチャマセンニュウ Locustella pleskeiなよ゙ があげられる.これらの種・亜種についてすDNAを用いた系統解析を行うことで混乱し ている類縁関係や系統上の問題の解决に新たな進展をもたらすことができる可能性が高い.

\section{5 ）絶隇種の系統}

日本にはすでに絶隇したと考えられる固有の種・覀種がいくつか知られており、これら 絶隇種・严種の系統関係についても興味深い問題が未解決のまま残されている，絶减した と思われる日本固有種としては, 現存するカラスバトColumba janthina との類縁関係が 示唆されているオガサワラカラスバトC. versicolor及びリュウキュウカラスバトC. jouyi（山階 1955, 森岡 1974), グァム島やポナぺ島に分布するズアカショウビン Halcyon cinnamomina のグァム島率亜種アカハラショウビンH. c. cinnamomina 之羽 色が酷似しており（山階1955），採集地の誤記載の可能性をす含めて独立種であることが 疑問視されているミヤコショウビン H. miyakoensis（森岡 1974，1989），ネパールに分 布するべニマュマシコPinicola subhimachalusなど様々な種との類縁が示唆されていて 意見が統一されていないオガサワラマシコChaunoproctus ferreorostris (Seebohm 1890, 籾山 1930, Morioka 1992), 今のところ類縁が全く判明していないオガサワラガビチョ ウZoothera terrestris の 5 種が知られている.

絶滅したと思われる日本固有亜種としては，ハシブトゴイ Nycticorax caledonicus crassirostris, マミジロクイナ Poliolimnas cinereus brevipes, ダイトゥミソサザイ Troglodytes troglodytes orii, ダイトウウグイス Cettia diphone restrictus, ダイトウ ヤマガラ Parus varius orii, ムコジマメグロ Apalopteron familiare familiare が知ら れている.これら種・要種の系統関係についてす不明な点が多く残されている。 また，日 本固有ではないが,キ夕夕キDryocopus javensis richardsi の対馬個体群及びカンムリッ クシガモ Tadorna cristata あ絶堿したと考えられており，特にカンムリックシガモにつ いては，他のックシガモTadorna属の種との系統関係すら明らかではない.

これらの絶滅種及び亜種のうち，標本が全く現存していないことが明らかになっている のはダイトゥゥグイスのみである．他の全ての種・亚種については国内むしくは国外の博 物館に標本が現存していることから，分子系統学的手法による系統解明が期待できる．た だし，前述の通り標本からのサンプル採取には，標本の破壊が伴う点について極めて慎重 に考慮する必要がある.

\section{分子データと分類（特に種分類について）}

分子系統学的研究の考察には分類に関わる部分が含まれることああるが，必ずしもこれ らの研究は分類の再考を主目的とはしておらず，扱った分類群の系統を探るのが主な目的 である. 系統学と分類学は明らかに別の学問分野であり, 系統解析の結果を必ずしも分類 学と結びつけて考える必要はない，しかし，実際には，分子データを用いた系統解析の結 果, 収敛進化が明らかになった場合（同種と考えられていた2つの分類群が，遣伝的には 異なる系統に所属していた場合など）や，塩基配列の分化程度が従来研究されてきた形態 などの分化程度と一致しない時などには，分類学的取り扱いについて言及している場合が 
多い.これまで行われた鳥類の分子系統学的研究においては，このような場合，明らかな 収敛進化を別にすれば，DNAの塩基配列データからのみではなく，生態や形態形質，分 布状况などす検討した上で考察をしていることが多い。

しかし, 最近では鳥類の塩基配列デー夕, 特に Cyt.b 領域に関しては多くの例が蓄積さ れてきているため, 塩基配列の分化程度之種・亜種の分類についての関連性が考察され始 めている. Helbig et al. (1995) がまとめたCyt.b 領域の分化率（2つの分類群で比較 された塩基配列にしめる塩基の置換の割合）は，亜種もしくは個体群の関係にある2つの 分類群間で最高 $2.6 \%$ 程度であった. 一方, 最も近縁な 2 種間の相違は $0.2 \sim 10 \%$ 以上まで 様々である．実際には別種に分類されている種間の相違が亜種間の相違よりる小さい例も 多い (Helbig et al. 1995). 覀種間の相違が2.6\%よりも大きい例もその後知られている ので (Leisler et al. 1997), これらの值については今後す変更が予测される.

今のところ, $2.6 \%$ Cyt.b 領域の塩基配列の相違を基準にそれ以上の相違が検出され た場合を種とするような，境界線は主張されて居らず，多くの論文の著者が塩基配列の分 化程度のみを使用しての種・亚種の線引きには否定的であることから (Leisler et al. 1997）今後も境界線として，この值が単独で利用されることはないと推测される。しかし， この值は分類の再検討を行う目安としては利用可能である. 塩基配列データの相違を目安 にして，亜種と分類されているが遭伝的には分化程度が大きい分類群や別種として分類さ れているが遺伝的には非常に近い分類群を検出し，これまで用いられていた分類形質の再 検討を行うことが可能となる。

塩基配列データを分類の根㚭として単独で使用するのは今のところ困難であるとしてあ, 今後, 分子系統の研究が增加することで急速に分類の再検討が行われる可能性は高く, 実 際欧米では分子系統学的研究例の增加に伴い多くの分類群で分類の見直しが行われている (Knox 1994, Martin 1996). しかし, 研究例が増加する一方で「サンプルがあり，分子 遗伝学的解析を行えばデータは得られるであろうし, 論文も菖けるだろう。そうした論文 を最近しばしば見かけるが分類学的視点を欠いた論文は,こうしたらこうなったというだ けのもので, ほとんど何の価値むない」という批判すある（森岡 1997．＼cjkstart分子デー夕を扱 う場合す対象とする分類群の持つ, 分類学的課題や問題点を把握しながら研究を進めるこ とは解析した系統関係を検討・考察する上でる重要であり, 分類学者から批判されないサ ンプリングを行う上での基礎とあなる.

\section{考察}

DNA を用いた系統解析は, 植物, 昆虫から哺乳類まで鳥類以外の広い分類群において, 日本ですすでに一般的な研究分野となりつつある.にあかかわらず鳥類においてのみ極端 にこの分野の発達が遅れているのは, 著者を含め,この国の現在の鳥類研究者の大半がフィー ルドワークを好み，実験室での分析を嫌う傾向があること，及び魅力的な研究課題を示し てこなかったことに原因があるように思われる. 形態などの形質を用いて系統の研究を行 う国内の研究者がほとんぞ絶㓕危惧種のような状態であることも，この分野の発達遅滞を 助長した一母であるかるしれない，前述した様に，鳥類においても日本列島及びその周辺 には分子系統学的研究課題が山積している.この点については国内の研究者よりあ海外の 
研究者の方が正確に認識しているらしく，欧米の研究者からのサンブル提供要請年々增 加している. また, 海外で発表される鳥類の分子系統学的研究論文の謝辞やサンプル提供 者として日本人の名を認めることは，決して希ではない，海外の研究者に彼らの欲しがる サンプルを提供して，この分野の研究を進めてあらうのむ悪くはない．あるいは，そうし た方が日本周辺の鳥類進化上の不明点が明らかになる日は早まるかむしれない.しかし， 必要な機器・薬品の入手が容易で, 手法の簡略化・自動化が進んだ現在, 国内です独自に 鳥類の分子系統学的䂧究を行うのは十分に可能である. 海外の研究者と協力して研究を進 める場合にも，一方的なサンプル提供ではなく，対等な意味での共同研究を行える素地を 形成することは，我が国の鳥類学に課せられた重要なデーマであろう.

分子系統学的分野で使用される分析手法としては，今後もダイレクトシークエンシング による解析が主流であり続ける確率は高いが, 非常に技術革新の速度が速い分野であるた め新たな手法が開発される可能性すある. 少なくとも DNA 抽出や増幅, 解析などの手法 は今後す簡略化と短時間化が急速に進むと思われる. 分析される領域や塩基数は現在のと ころ増加傾向にあるが, 今後あ限りなく増加してゆく可能性は低いと推測される. 現在鳥 類の系統解析によく利用されている mtDNAの3 領域 (12SrRNA, Cyt.b, Control) に ついてフルベース（全塩基対）を読みとり比較することができれば，少なくとあ低次份類 群間（属, 種, 垔種レベル) の系統関係を明らかにするには十分であると思われる. 当然 より系統解析に適した領域が発見されれば, 解析に利用される領域の変更は十分に考えら れる、しかし, 当面は mtDNAの他の領域についての探求上りる, 遺伝様式の異なる核 DNAにおいて利用可能な領域を確定することの方が急務となるであろう．得られた塩基 配列データから系統推定を行うための手法やそれを表現するための方法, 信頼性を統計的 に検討する手法は，今後も引き続き改良が行われると思われる，系統学的研究において提 示された系統樹を理解し，信頼性などを判断するには, これらの手法の理解が不可欠であ る. 系統学に直接関与しない鳥類研究者すある程度これらの手法を理解することで, 質の 悪い系統樹を無批判に信じ込むような事態を防ぎ，示された系統樹の善し悪しを自ら判断 することができる.

日本の鳥類分類学が分子系統学の成果を今後どの様に取り込むのかは明らかでないが, 海外の状況から推測して, 現在使用されている分類が再検討を迫られる可能性は高い.た だし，鳥類系統学（分子系統学を含む）と鳥類分類学の研究者を合わせても片手の指にも 足りない現状では，現時点での活発な論議はほとんど望めそうにない。

いずれにせよ, 分子系統学的研究が増加することにより, 日本列島周辺に解かれないま ま放置されている多くの鳥類進化上の謎に新たな視点からの考察が加えられ, 鳥類進化に 関する研究が急速に進展する可能性は非常に高い，鳥類の進化を明らかにするには，分類 群の分岐の順序と分化程度が判明するのみでは不十分であり, 形態・生態・生理などあら ゆる面からの研究と論議が不可欠である. しかし，DNAの塩基配列データを利用した系 統解析がその鍵を握る分野となる可能性は非常に高いと思われる.

本稿をきっかけに鳥類分子系統学に興味を持つ研究者が增加し, 鳥類の進化についての 研究が今以上に活発になれば幸いである. 
と様々な援助をしていただいた，また，東京大学の石田健氏，立教大学の上田恵介氏，農林水産省森 林総合研究所の川路則友氏，国立科学博物館の森岡弘之氏にも様々な面でご指導をいただいた。これ らの方々ならびに発表の場を与えていただいた九州大学の江口和洋氏に心からの謝意を表したい．

\section{摘 要}

DNA を用いた鳥類の系統解析は近年急速に発達し，現在では多くの研究例が知られている. DNA の中でも mtDNA は近縁な分類群の系統解析に適した性質を多く持つ。だし，mtDNAの みを解析に使用した場合には，異種間浸透などによって誤った系統を推定する可能性す知られている. DNA を採取するためのサンプルとしては血液，組織，羽毛などが利用可能で，標本からのDNA 採 取も可能である. 分析は DNA 抽出, 堌愊, 㙁基配列決定の順で行われる，得られた塩基配列デー タから，系統推定法によって分類群の系統関係が推定される. 得られた系統樹についてはその信頼性 を統計的処理によって判断することが可能である．日本周辺には，鳥類の系統や進化に関する研究課 題が山積されており，これらの課題を解明するには分子系統学的側面からの研究が不可欠である. 今 のところ DNA の㙁基配列データのみを利用して種・要種の境界を決めることは困難であるが，鳥 類の分類を再祫討する上での非常に重要な情報となる可能性が高いＤNA の塩基配列データを用い た系統解析が，鳥類の進化を明らかにする上で大きな役割を担う手法となることは間違いなく，この 分野の国内での早期の発展が望まれる。

\section{引 用 文 献}

奄美野鳥の会, 1997.オオトラッグミのさえずり個体のセンサス結果（1996年春). Strix. 15: 117121.

Alison, R. M., 1977. Homing of subadult Oldsquaws. Auk 94: 383-384.

American Ornithologists' Union, 1988. Guidelines for use of wild birds in research. Supplement to the Auk 105: 1a*41a.

American Ornithologists' Union, 1997. Forty-first supplement to the American Ornithologist' Union check-list of North American birds. Auk 114: 542-552.

Arctander, P. \& Fjeldså, J., 1994. Avian tissue collections for DNA analysis. Ibis 136: 359-360.

Arctander, P., Folmer, O. \& Fjeldså, J., 1996. The phylogenetic relationships of Berthelot's Pipit Anthus berthelotii illustrated by DNA sequence data, with remarks on the genetic distance between Rock and Water Pipits Anthus spinoletta. Ibis 138: 263-272.

Austin, J. J., 1996. Molecular phylogenetics of Puffinus Shearwaters: Preliminary evidence from mitochondrial cytochrome $b$ gene sequences. Molecular Phylogenetics and Evolution 6: 77-88.

Avise, J. C. \& Ball, R. M., Jr., 1991. Mitochondrial DNA and avian microevolution. Acta XX Congressus Internationalis Ornithologici 1: 514-524.

Avise, J.C., Alisauskas, R.T., Nelson, W.S. \& Ankney, C.D., 1992. Matriarchal population genetic structure in an avian species with female natal philopatry. Evolution 46: $1084-1096$.

馬場芳之, 1996. 日本産ライチョウ類の道伝的多様性と保全. 九州大学大学院比較社会文化研究科 平成 8 年度修士論文.

Baker, A. J. \& Marshall, H. D., 1997. Mitochondrial control region sequences as tools for understanding evolution. Mindell, D. P. (ed.) Avian Molecular evolution and systematics: 51-82. Academic Press, London. 
Baker, M. C., 1981. A muscle biopsy procedure for use in electrophoretic studies of birds. Auk, 98: 392-393.

Ball, R. M., Jr. \& Avise, J. C., 1992. Mitochondrial DNA phylogeographic differentiation among avian populations and the evolutionary significance of subspecies. Auk 109: $626-636$.

Bates, J. M. \& Zink, R. M. 1994. Evolution into the Andes: Molecular evidence for species relationships in the genus Leptopogon. Auk 111: 507-515.

Bleiweiss, R., Kirsch, J. A. W. \& Matheus J. C., 1994. DNA-DNA hybridization evidence for subfamily structure among Hummingbirds. Auk 111: 8-19.

Bretagnolle, V., Attie, C. \& Pasquet, E., 1998. Cytochrome-B evidence for validity and phylogenetic relationships of Pseudobulweria and Bulweria (Procellariidae). Auk 115: 188-195.

Brooke, M. DE L. \& Rowe, G., 1996. Behavioural and molecular evidence for specific status of light and dark morphs of the Herald Petrel Pterodroma heraldica. Ibis 138: $420-432$.

Brown, G. G., Gadeleta, G., Pepe, G., Saccone, C. \& Sbisa, E., 1986. Structual conservation and variation in the $\mathrm{D}$-loop-containing region of vertebrate mitochondrial DNA. J. Mol. Biol: 192: 503-511.

Brown, W. M., George, M., Jr., \& Wilson, A. C., 1979. Rapid evolution of animal mitochondrial DNA. Proc. Natl. Acad. Sci. USA 76: 1967-1971.

Burns, K. J., 1998. Molecular phylogenetics of genus Piranga: Implications for biogeography and the evolution of morphology and behavior. Auk 115: 621-634.

Chikuni, K., Minaka, N. \& Ikenaga, H., 1996. Molecular phylogeny of some passeriformes, based on cytochrome b sequences. J. Yamashina Inst. Ornithol. 28: $1-8$.

Christidis, L., Davies, K., Westerman, M., Christian P. D. \& Schodde, R., 1996a. Molecular assessment of the taxonomic status of Cox's Sandpiper. Condor 98: 459-463.

Christidis, L., Leeton, P. R. \& Westerman, M., 1996b. Were bowerbirds part of the New Zealand fauna? Proc. Natl. Acad. Sci. USA 93: 3898-3901.

Cicero, C. \& Johnson, N. K., 1995. Speciation in Sapsuckers (Sphyrapicus): III . Mitochondrial-DNA sequence divergence at the cytochrome-B locus. Auk 112: 547-563.

Cooke, F., MacInnes, C. D. \& Prevett, J.P., 1975. Gene flow between breeding populations of lesser Snow Geese. Auk 92: 493-510.

Cooper, A., 1994. DNA from museum specimens. Herrmann, B. \& Hummel, S. (eds.) Ancient DNA: 149-165. Springer-Verlag, New York.

Cooper, A., Mourer-Chauvire, C., Chambers, G. K., von Haeseler, A., Wilson, A. C. \& Pääbo, S. 1992. Independent origins of New Zealand maos and Kiwis. Proc. Natl. Acad. Sci. USA 89: 8741-8744.

Crowe, T. M., Harley, E. H., Jakutowicz, M. B., Komen, J. \& Crowe, A. A. 1992. Phylogenetic, taxonomic and biogeographical implications of genetic, morphological, and behavioral variation in Francolins (Phasianidae: Francolinus). Auk 109: 24-42.

Dawson, R. J. G., Parkin, D. T., Cubitt, M., Won, P. \& Zino, F. J. A., 1997. DNA amplification and sequencing of unidentified Dark-rumped Storm-Petrels Oceanodroma in the North Atlantic Ocean. Bull. Kor. Assoc. Wildl. Conserv. 1: 67-72.

Degnan, S. M. \& Moritz, C., 1992. Phylogeography of mitochondrial DNA in two species of White-eyes in Australia. Auk 109: 800-811.

Deignan, H. G., 1958. The systematic position of the bird genus Apalopteron. Proc. U. S. Natl. Mus. 108: 133-136.

Desjardins, P. \& Morais, R., 1990. Sequence and gene organization of the chicken 
mitochondrial genome. J. Mol. Biol. 212: 599-634.

Dessauer, H. C., Cole, C. J. \& Hafner, M. S. 1996. Collection and storage of tissues. Hillis, D. M., Moritz, C. \& Mable, B. K. (eds.) Molecular Systematics: 29-47. Sinauer Associates, Sunderland.

Dittmann, D. L. \& Zink, R. M., 1991. Mitochondrial DNA variation among Phalaropes and Allies. Auk 108: 771-779.

Dodge, A. G., Fry, A. J., Blackwell R. C. \& Zink, R. M., 1995. Comparison of phylogenies derived from two molecular data sets in the avian genera Pipilo and Spizella. Wilson Bull. 107: 641-654.

Edwards, S. V., 1993. Mitochondrial gene genealogy and gene flow among island and mainland populations of a sedentary songbird, the Gray-crowned Babbler (Pomatostomus temporalis). Evolution 47: 1118-1137.

Edwards, S. V. \& Wilson, A. C., 1990. Phylogenetically informative Iength polymorphism and sequence variability in mitochondrial DNA of Australian songbirds (Pomatostomus). Genetics 126: 695-711.

Edwards, S. V., Arctander, P. \& Wilson, A. C., 1991. Mitochondrial resolution of a deep baranch in the genealogical tree for perching birds. Proc. R. Soc. Lond. B 243: $99-107$.

Ellegren, H., 1991. DNA typing of Museum birds. Nature 354: 113.

Ellegren, H., 1994. Genomic DNA from museum bird feathers. Herrmann, B. \& Hummel, S. (eds.) Ancient DNA: 211-217. Springer-Verlag, New York.

Ellsworth, D. L., Honeycutt, R. L. \& Silvy, N. J., 1995. Phylogenetic relationships among North American grouse inferred from restriction endonuclease analysis of mitochondrial DNA. Condor 97: 492-502.

Ellsworth, D. L., Honeycutt, R. L. \& Silvy, N. J., 1996. Systematics of Grouse and ptarmigan determined by nucleotide sequences of the mitochondrial cytochrome-B gene. Auk 113: 811-822.

Ellsworth, D. L., Honeycutt, R. L., Silvy, N. J., Rittenhouse, K. D. \& Smith, M. H., 1994. Mitochondrial-DNA and nuclear-gene differentiation in North American Prairie Grouse (Genus Tympanuchus). Auk 111: 661-671.

Felsenstein, J., 1996. PHYLIP: Phylogeny inference package, Version 3.572. Computer software and documentation distributed by the author. Department of Genetics, University of Washington.

Freitag, S. \& Robinson, T. J., 1993. Phylogeographic patterns in mitochondrial DNA of the Ostrich (Struthio camelus). Auk 110: 614-622.

Friesen, V. L., Piatt, J. F. \& Baker, A. J., 1996. Evidence from cytochrome B sequences and allozymes for a 'new' species of alcid: The Long-billed Murrelet (Brachyramphus perdix). Condor 98: 681-690.

藤村和男, 1948. アカコッコに就いて。鳥 12: 57-62。

Gill, F. B. \& Slikas, B., 1992. Patterns of mitochondrial DNA divergence in North American Crested Titmice. Condor. 94: 20-28.

Gill, F. B., Mostrom, A. M. \& Mack, A. L., 1993. Speciation in North American Chickadees: I . Patterns of mtDNA genetic divergence. Evolution 47: 195-212.

Goodwin, D., 1968. Notes on Woodpeckers (Picidae). Bull. Br. Mus. (Nat. Hist.) Zool. 17: $1-44$

Goodwin, D., 1986. Crows of the world.-second edition. The British Museum (Natural History). London.

Greenberg, R., Cordero, P. J., Droege, S. \& Fleischer, R: C., 1998. Morphological adaptation with no mitochondrial DNA differentiation in the coastal plain Swamp Sparrow. Auk 115: 706-712.

Greenwood, P.J.\& Harvey, P.H., 1982. The natal and breeding dispersal of birds. Ann. Rev. Ecol. Syst. 13: 1-21.

Hackett, S. J., 1995. Molecular systematics and zoogeography of flowerpiercers in the 
Diglossa baritula complex. Auk 112: 156-170.

Hare, M. P. \& Shields, G. F., 1992. Mitochondrial-DNA variation in the polytypic Alaskan Song Sparrow. Auk 109: 126-132.

Harvey, P. H. \& Pagel, M. D., 1991. The comparative method in evolutionaly biology. Oxford University Press, London.

長谷部光泰, 1996. 分子系統学のすすめ. 岩柣邦男・馬渡峻辅（編）生物の多様性. 裳華房, 東京.

長谷川政美・岸野洋久, 1996. 分子系統学. 岩波書店, 東京.

Helbig, A. J., Martens, J., Seibold, I., Henning, F., Schottler, B. \& Wink, M., 1996. Phylogeny and species limits in the Palaearctic Chiffchaff Phylloscopus collybita complex: mitochondrial genetic differentiation and bioacoustic evidence. Ibis 138: 650-666.

Helbig, A. J., Seibold, I., Martens, J. \& Wink, M., 1995. Genetic differentiation and phylogenetic relationships of Bonelli's Warbler Phylloscopus bonelli and Green Warbler P. nitidus. Journal of Avian Biology 26: 139-153.

Helm-Bychowski, K. \& Cracraft, J., 1993. Recovering phylogenetic signal from DNA sequences: Relationships within the corvine assemblage (Class Aves) as inferred from complete sequences of the mitochondrial DNA cytochrome-b gene. Mol. Biol. Evol. 10: 1196-1214

Higuchi, H. \& Hirano, T., 1989. Breeding season, courtship behaviour, and territoriality of White and Japanese Wagtails Motacilla alba and $M$. grandis. Ibis 131: $578-588$.

Higuchi, H., Minton, J. \& Katsura, C., 1995. Distribution and Ecology of birds of Japan. Pacific Science 49: 69-86.

Houde, P. \& Braun, M. J., 1988. Museum collections as a source of DNA for studies of avian phylogeny. Auk 105: 773-776.

Houde, P., Cooper, A., Leslie, E., Strand, A. E. \& Montano, G. A., 1997. Phylogeny and evolution of $12 \mathrm{~S}$ rDNA in Gruiformes (Aves). Mindell, D. P. (ed.) Avian Molecular evolution and systematics: 121-158. Academic Press, London.

石田健, 1996. 鳥類の生態研究に招ける DNA 分析. 山階鳥研報 28: 51-80.

Ishihara, T., 1986. The Amami Ground Thrush distinct from the White's Ground Thrush. Strix 5: 60-61.

Jones, D. A. \& Gibbs, H. L., 1997. Intra- and interspecific sequence variation in a portion of the mitochondrial ND6 gene in Cuckoos. Condor 99: 815-818.

柿沢亮三, 1991. DNA 交雑法による鳥類の新しい分類。野鳥 542: 33.

杮沢亮三・鈴木仁・土屋公幸, 1996. ミトコンドリアDNAの変異加ら見たカグーの系統分類. カグー 研究会報告. 37-41.

金田秀貴・米川博通，1998。ミトコンドリアDNAにみられる母性遺伝の不思議. 䕗伝 52: 27-31.

粕谷英一, 1995. 最近の比較生態学の方法の発展-種間比較には系統関係が必要である-. 日本生態学 会誌 45: 277-288.

Kawaji, N. \& Higuchi, H., 1989. Distribution and status of the Ryukyu Robin Erithacus komadori. J. Yamashina Inst. Ornithol. 21: 224-233.

Kawaji, N., Higuchi, H. \& Hori, H., 1989. A new breeding record of the Izu Island Thrush Turdus celaenops from the Tokara Islands, southwest Japan. Bull. B. O. C. 109: 93-95.

Kessler, L. G. \& Avise, J. C., 1985. A comparative description of mitochondrial DNA differentiation in selected avian and other vertebrate genera. Mol. Biol. Evol. 2: $109-125$.

木村資生, 1988. 生物進化を考元る. 岩波書店, 東京.

Knox, A., 1994. Lumping and splitting of species. British Birds 87: 149-159.

Kocher, T. D., Thomas, W. K., Meyer, A., Edwards, S. V., Pååbo, S., Villablance, F. X. \& Wilson, A. C., 1989. Dynamics of mitochondrial DNA evolution in animals: Amplification and sequencing with conserved primers. Proc. Natl. Acad. Sci. USA 86: $6196-6200$. 
Krajewski, C. \& Fetzner, J. W., Jr., 1994. Phylogeny of Cranes (Gruiformes: Gruidae) based on cytochrome- $B$ DNA sequences. Auk 111: 351-365.

Krajewski, C. \& King, D. G., 1996. Molecular divergence and phylogeny: Rates and patterns of cytochrome b evolution in cranes. Mol. Biol. Evol. 13: 21-30.

Krajewski, C. \& Wood, T. C., 1995. Mitochondrial DNA relationships within the Sarus Crane species group (Gruiformes: Gruidae). Emu 95: 99-105.

Kuroda, N., 1957. Notes on the evolution in the Eurasian Jay, Garrulus glandarius. Jour. Fac. Sci. Hokkaido Univ. Ser. VI, Zool. 13: 72-77.

黒田長久, 1972. 動物地理学. 共立出版, 東京.

黒田長久・真野徹・尾崎清明, 1984. クイナ科とその保讙について.山階鳥類研究所50年のあゆみ: 36-57. 山階鳥類研究所.

Kvist, L., Ruokonen, M., Orell, M. \& Lumme, J., 1996. 'Evolutionary patterns and phylogeny of tits and chickadees (genus Parus) based on the sequence of the mitochondrial cytochrome $b$ gene. Ornis Fennica 73: 145-156.

Lanyon, S. M. \& Hall, J. G., 1994. Reexamination of barbet monophyly using mitochondrial-DNA sequence data. Auk 111: 389-397.

Leeton, P. R., Christidis, L., Westerman, M. \& Boles, W. E., 1994. Molecular phylogenetic affinities of the Night Parrot (Geopsittacus occidentaris) and the Ground Parrot (Pezoporus wallicus). Auk 111: 833-843.

Leeton, P., Christidis, L. \& Westerman, M., 1993. Feathers from museum bird skinsA good source of DNA for phylogenetic studies. Condor 95: 465-466.

Leisler, B., Heidrich, P., Schulze-Hagen, K. \& Wink, M., 1997. Taxonomy and phylogeny of Reed warblers (genus Acrocephalus) based on mtDNA sequences and morphology. Journal für Ornithologie 138: 469-496.

Li, Q., Lin, J., Wen, W., Li, W. \& Zheng, Y., 1998. Diversity of mitochondrial DNA in eight species of strigiformes. Acta Zool. Sinica 44: 94-101. (In Chinese with English Summery).

Lougheed, S. C. \& Handford, P. 1993. Mitochondrial DNA hyperdiversity and vocal dialects in a subspecies transition of the Rufous-collared Sparrow. Condor 95: 889-895.

Lynch, M. \& Jarrell, P. E., 1993. A method for calibrating molecular clocks and its application to animal mitochondrial DNA. Genetics 135: 1197-1208.

Madge, S. \& Burn, H., 1994. Crows and Jays. Christopher Helm, London

Martin, A. P. \& Palumbi, S. R., 1993. Body size, metabolic rate, generation time, and the molecular clock. Proc. Natl. Acad. Sci. USA 90: 4087-4091.

Martin, G., 1996. Birds in double trouble. Nature 380: 666-667.

Meinertzhagen, C.R., 1928. Some biological problems connected with the Himalaya. Ibis: $480-533$.

Meinertzhagen, C.R.,1951. Some relationships between African, Oriental, and Palaearctic genera and species, with a review of the genus Monticola. Ibis 93: 443-459.

三中信宏, 1997, 生物系統学, 東京大学出版会, 東京

Mindell, D. P. \& Honeycutt, R. L., 1990. Ribosomal RNA in vertebrates: Evolution and phylogenetic applications. Ann. Rev. Ecol. Syst. 21: 541-566.

Miranda, H. C., Jr., Kennedy, R. S. \& Mindell, D. P., 1997. Phylogenetic placement of Mimizuku gurneyi (Aves: Strigidae) inferred from mitochondrial DNA. Auk 114: $315-323$.

籾山徳太郎, 1930. 小笠原諸島並に硫黄列島産の鳥類に就いて. 日本生物地理学会会報 1: 89-186.

Monteros, A. E. D. L. \& Cracraft, J., 1997. Intergeneric relationships of the new world Jays inferred from cytochrome b gene sequences. Condor 99: 490-502.

Moore, W. S. \& DeFilippis, V. R. 1997. The window of taxonomic resolution for phylogenies based on mitochondrial cytochrome b. Mindell, D. P. (ed.) Avian Molecular evolution and systematics: 83-119. Academic Press, London. 
森岡弘之, 1974. 琉球列島の鳥相とその起源. 国立科博専報 7: 203-211.

Morioka, H., 1982. Status of Brown Thrush Turdus chrysolaus of Japan, with special reference to the population in the Fuji area. Mem. Natn. Sci. Mus. 15: 213-220.

森岡弘之, 1989. ヤンバルクイナとミヤコショウビンー琉球の鳥 2 題. 日本の生物 3: 19-24.

森岡弘之, 1990. トカラ列島の繁殖鳥類とその起源. 国立科博専報 23: 151-166.

Morioka, H., 1992. Relationships of Ogasawara Islands Grosbeak Chaunoproctus ferreorostris (Aves, Fringillidae). Bull. Natn. Sci. Mus., Tokyo, Ser.A. 18: 45-49.

森岡弘之, 1997. 日本の鳥類目録之鳥類分類学. 日本動物大百科. 4 . 鳥類II: 175-176. 平凡社, 東 京

Moum, T. \& Johansen, S., 1992. The mitochondrial NADH dehydrogenase subunit 6 (ND6) gene in Murres: relevance to phylogenetic and population studies among birds. Genome 35: 903-906.

Mundy, N. I., Unitt, P. \& Woodruff, D. S., 1997. Skin from feet of museum specimens as a non-destructive source of DNA for avian genotyping. Auk 114: 126-129.

村松正實, 1990. ラボマニュアル遗伝子工学. 丸善, 東京.

Murata, K., Itoh, Y., Ogawa, A. \& Mizuno, S., 1998. Sexing the Oriental White Stork Ciconia boyciana by PCR using a single plucked feather as a source of DNA. Jpn. J. Ornithol. 46: 157-162.

Murray, B. W., McGillivray, W. B., Barlow, J. C., Beech, R. N. \& Strobeck, C., 1994. The use of the cytochrome $B$ sequence variation in estimation of phylogeny in the Vireonidae. Condor 96: 1037-1054.

Nagata, J., Masuda, R. \& Yoshida, M. C., 1995. Nucleotide sequences of the cytochrome $b$ and the 12S rDNA genes in the Japanese Sika Deer Cervus nippon. J. Mamm. Soc. Japan 20: 1-8.

中村一恵, 1985. 日本列島におけるセキレイ属近縁2種の地理的分布の变遷 (予報). 神奈川県立博物 館研究報告 16: 23-36.

中村一恵, 1987. 八クセキレイとセグロセキレイの分布総説. 日本の生物 1: 44-51.

中村一恵, 1992. オナガの分布. 世界編. 野鳥 545: 20.

中山広樹，1996. バイオ実験イラストレイテッド(3)本当にふえる PCR. 秀潣社, 東京.

中山広樹・西方敬人，1995a，バイオ実験イラストレイテッド(1)分子生物学実験の基脴. 秀潤社, 東 京.

中山広樹・西方敬人，1995b. バイオ実験イラストレイテッド(2)遭伝子解析の基䃈. 秀潤社, 東京.

日本鳥学会目録編集委貝会, 1997. 日本産鳥類リス卜. 日本鳥学会誌 46: 59-91.

日本鳥学会, 1974. 日本鳥類目録. 学研, 東京.

西海 功, 1995. 羽毛採取があつ可能性一将来の DNA 分析のために. 鳥学ニュース 56: 6 .

西海 功, 1997. DNA 多型分析の生態学への応用. 山岸哲 (編) 鳥類生態学入門: 158-170. 筑地晴 館, 東京

Nunn, G. B., Cooper, J., Jouventin, P., Robertson, C. J. R. \& Robertson, G. G. 1996. Evolutionary relationships among extant Albatrosses (Procellariformes: Diomedeidae) established from complete cytochrome-B gene sequences. Auk 113: $784-801$.

Ohta, T., 1992. The nearly neutral theory of molecular evolution. Annu. Rev. Ecol. Syst. 23: 263-286.

Pasquet, E., 1998. Phylogeny of the nuthatches of the Sitta canadensis group and its evolutionary and biogeographic implications. Ibis 140: 150-156.

Paterson, A. M., Wallis, G. P. \& Gray, R. D., 1995. Penguins, Petrels, and Parsimony: Does cladistic analysis of behavior reflect sea birds phylogeny? Evolution 49: 974-989.

Quinn, T. W. \& Wilson, A. C., 1993. Sequence evolution in and around the mitochondrial control region in birds. J. Mol. Evol. 37: 417-425.

Quinn, T. W., 1997. Molecular evolution of the mitochondrial genome. Mindell, D. P. (ed.) Avian Molecular evolution and systematics: 3-28. Academic Press, London.

Quinn, T. W., Shields, G. F. \& Wilson, A. C., 1991. Affinities of the Hawaiian Goose 
based on two types of mitochondrial DNA data. Auk 108: 585-593.

Ramirez, V., Savoie, P. \& Morais, R., 1993. Molecular characterization and evolution of a Duck mitochondrial genome. J. Mol. Evol. 37: 296-310.

Rhymer, J. M. Williams, M. J. \& Braun, M. J., 1994. Mitochondrial analysis of gene flow between New Zealand Mallards (Anas platyrhynchos) and Grey Ducks (A. superciliosa). Auk 111: 970-978.

Richman, A. D. \& Price T., 1992. Evolution of ecological differences in the Old World Jeaf warblers. Nature 355: 817-821.

Rising, J. D. \& Avise, J. C., 1993. Application of genealogical-concordance principles to the taxonomy and evolutionary history of the Sharp-tailed Sparrow (Ammodramus caudacutus). Auk 110: 844-856.

Ryan, P. G., Hood, I., Bloomer, P., Komen, J. \& Crowe, T. M., 1998. Barlow's Lark: a new species in the Karoo Lark Certhilauda albescens complex of southwest Africa. Ibis 140: 605-619.

酒井秀嗣, 1997, ホルモンと繁殖活動. 山岸哲 (編) 鳥類生態学入門: 143-157. 築地書館, 東京

Seebohm, H., 1890. The birds of the Japanese empire. P.H.Porter, London.

Seibold, I., Helbig, A. J., Meyburg, B. -U., Negro, J. J. \& Wink, M. 1996. Genetic differentiation and molecular phylogeny of European Aquila Eagles according to cytochrome b nucleotide sequences. Meyburg, B. -U. \& Chancellor, R. D. (eds.) Eagle Studies: 1-15.

Seutin, G., Ratcliffe, L. M. \& Boag, P. T., 1995. Mitochondrial DNA homogeneity in the phenotypically diverse Redpoll Finch complex. Evolution 49: 962-973.

Seutin, G., White, B. N. \& Boag, P. T., 1991. Preservation of avian blood and tissue samples for DNA analyses. Can. J. Zool. 69: 82-90.

Sheldon, F. H. \& Gill, F. B., 1996. A reconsideration of songbird phylogeny, with emphasis on the evolution of titmice and their sylvioid relatives. Syst. Biol. 45: 473-495.

Sheldon, F. H. \& Winkler, D. W., 1993. Intergeneric phylogenetic relationships of Swallows estimated by DNA-DNA hybridization. Auk 110: 798-824.

Sheldon, F. H., Slikas, B., Kinnarney, M., Gill, F. B., Zhao, E. \& Silverin, B., 1992. DNA-DNA hybridization evidence of phylogenetic relationships among major lineages of Parus. Auk 109: 173-185.

Sheldon, F. H., McCracken, K. G. \& Stuebing, K. D., 1995. Phylogenetic relationships of the Zigzag Heron (Zebrilus undulatus) and White-crested Bittern (Tigriornis leucolophus) estimated by DNA-DNA hybridization. Auk 112: 672-679.

Shields, G. F. \& Wilson, A. C., 1987. Calibration of mitochondrial DNA evolution in geese. J. Mol. Evol, 24: 212-217.

Shirihai, H., Roselaar, C. S., Helbig, A. J., Barthel, P. H. \& Loon, A. J., 1995. Identification and taxonomy of large Acrocephalus warblers. Dutch Birding 17: $229-239$.

Short, L.L., 1973a. Notes on Okinawan Birds and Ryukyu Island zoogeography. Ibis 115: $264-267$.

Short, L.L., 1973b. Habits, relationships, and conservation of the Okinawa Woodpecker. Wilson Bull. 85: 5-20.

Sibley, C. G. \& Ahlquist, J. E., 1990. Phylogeny and classification of birds. a study in molecular evolution. Yale University Press, New Haven.

Sibley, C. G., 1997. DNAでみた鳥の世界. biohistory 5: 4-11. (加藤和人翻訳の訳文.)

Slikas, B., Sheldon, F. H. \& Gill, F. B., 1996. Phylogeny of titmice (Paridae): I . Estimate of relationships among subgenera based on DNA-DNA hybridization. J. Avian Biol. 27: 70-82.

Smith, E. F. G., Arctander, P., Fjeldså, J. \& Amir, O. G., 1991. A new species of Shrike (Laniidae: Laniarius) from Somalia, verified by DNA sequence data from the only known individual. Ibis 133: 227-235. 
Sowls, L.K., 1955. Prairie Ducks. University of Nebraska Press, London.

Springer, M. S., Higuchi, H., Ueda, K., Minton, J. \& Sibley, C. G., 1995. Molecular evidence that the Bonin Islands "Honeyeater" is a White-eye. J. Yamashina Inst. Ornithol. 27: 66-77.

Srikwan, S. \& Woodruff, D. S., 1998. DNA Sequence variation and Hornbill conservation. Poonswad, P. (ed.) The Asian Hornbills: Ecology and Conservation: 69-82. National Center for Genetic Engineering and Biotechnology.

Stangel, P. W., 1986. Lack of effects from sampling blood from small birds. Condor 88: $244-245$.

Stewart, C.-B., Schilling, J. W \& Wilson, A. C., 1987. Adaptive evolution in the stomach lysozymes of foregut fermenters. Nature 330: 401-404.

Swofford, D. L., 1993. PAUP: Phylogenetic analysis using parsimony, Version 3.1. Computer software. Smithsonian Institution, Washington.

Swofford, D. L., Olsen, G. J., Waddell, P. J. \& Hillis, D. M., 1996. Phylogenetic inference. Hillis, D. M., Moritz, C. \& Mable, B. K. (eds.) Molecular Systematics: 407-514. Sinauer Associates, Sunderland.

Taberlet, P. \& Bouvet, J., 1991. A single plucked feather as a source of DNA for bird genetic studies. Auk 108: 959-960.

高田啓介, 1995. 博物館魚類標本を用いたDNA解析の試み. 国立科学博物館ニュース 318: 4-9.

高木利久・金久實，1996. ケ゚ノムネットのデータベース利用法. 共立出版，東京.

高畑尚之, 1986. 細胞質オルガネラDNAの変異と進化(2). 遗伝 40: 64-70.

Tarr, C. L., 1995. Primers for amplification and determination of mitochondrial control-region sequences in oscine passerines. Molecular Ecology 4: 527-529.

Tarr, C. L. \& Fleischer, R. C., 1993. Mitochondrial-DNA variation and evolutionary relationships in the Amakihi complex. Auk 110: 825-831.

Tuohy, J. M., McHugh, K. P. \& Kloet, S. R. DE, 1992. Systematic relationships among some Anitini as derived from restriction-endonuclease analysis of a repeated DNA component. Auk 109: 465-473.

Thomas, R. H., 1994. Analysis of DNA from natural history museum collections. Molecular Ecology and Evolution 311-321.

Ticehurst, C. B., 1938. A systematic review of the genus Phylliscopus. The British Museum, London.

上田恵介, 1997. DNAはドラエモンのポケット?ーアジア・太平洋地域における鳥類の進化学的研 究の重要性. 日本鳥学会誌 45: 247-249.

上島 励, 1996. 系統樹をつくる. 岩柣邦男・馬渡畯辅（編）生物の多様性. 裳華房, 東京.

Udvardy, M. D. F., 1969. Dynamic Zoogeography. Van Nostrand Reinhold, New York.

Utter, J. M., 1971. A technique for sampling blood from small passerines. Auk 88: $169-171$.

Voelker, G. \& Edwards, S. V., 1998. Can weighting improve bushy trees? Models of cytochrome $b$ evolution and the molecular systematics of Pipits and Wagtails (Aves: Motacillidae). Syst. Biol. 47: 589-603.

和田 洋・片山智恵・佐藤矩行, 1992.18 SrDNA 分子からたどる動物の系統・類縁関係. 遗后 46: $51-56$.

Watada, M., Jitsukata, K. \& Kakizawa, R., 1995. Genetic divergence and evolutionary relationships of the old and new world Emberizidae. Zoological Science 12: 71-77.

Wenink, P. W. \& Baker A. J., 1996. Mitochondrial DNA lineages in composite flocks of migratory and wintering Dunlins (Calidris alpina). Auk 113: 744-756.

Wenink, P. W., Baker A. J. \& Tilanus, M. G. J., 1994. Mitochondrial control-region sequences in two shorebird species, the Turnstone and the Dunlin, and their utility in population genetic studies. Mol. Biol. Evol. 11: 22-31.

Williamson, K., 1976. Identification for ringers. The genus Phylloscopus. British Trust for Ornithology. 
Winker, K., 1994. Divergence in the mitochondrial DNA of Empidonax traillii and E. alnorum, with notes on hybridization. Auk 111: 710-713.

Winker, K., Braun, M. J. \& Graves, G. R., 1996. Voucher specimens and quality control in avian molecular studies. Ibis 138: 345-346.

Winkler, D. W. \& Sheldon, F. H., 1993. Evolution of nest construction in swallows (Hirundinidae): A molecular phylogenetic perspective. Proc. Natl. Acad. Sci. USA 90: 5705-5707.

Wood, T. C. \& Krajewski, C., 1996. Mitochondrial DNA sequence variation among the subspecies of Sarus Crane (Grus antigone). Auk 113: 655-663.

山階芳璒, 1941. 琉球列島特産鳥類三種の分類学的位圆と生物地理学的意義に就いて。 Biogeographica 3: 319-328.

山階芳磨, 1942. 伊豆七島の鳥類. 鳥 11: 191-270.

山階芳魔, 1955. 琉球列島における鳥類分布の境界線, 日本生物地理学会会報 16-19: 371-375.

山階芳磨, 1986. 世界鳥類和名辞典. 大学青林, 東京.

Yamashina, Y. \& Mano, T., 1981. A new species of Rail from Okinawa Island. J. Yamashina Inst. Ornithol. 13: 147-152.

Zink, R. M. 1991. The geography of mitochondrial DNA variation in two sympatric sparrows. Evolution 45: 329-339.

Zink, R. M. 1994. The geography of mitochondrial DNA variation, population structure, hybridazation, and species limits in the Fox Sparrow (Passerella iliaca). Evolution 48: 96-111.

Zink, R. M. \& Blackwell R. C., 1998. Molecular systematics of the Scaled Quail complex (Genus Callipepla). Auk 115: 394-403.

Zink, R. M. \& Dittmann, D. L., 1993. Population structure and gene flow in the Chipping Sparrow and a hypothesis for evolution in the genus Spizella. Wilson Bull. 105: 399-413.

Zink, R. M. \& McKitrick, M. C., 1995. The debate over species concepts and its implications for ornithology. Auk 112: 701-719.

Zink, R. M., Blackwell R. C. \& Rojas-Sato, O., 1997. Species limits in the Le Conte's Thrasher. Condor 99: 132-138.

Zink, R. M., Dittmann, D. L. \& Rootes, W. L., 1991a. Mitochondrial DNA variation and the phylogeny of Zonotrichia. Auk 108: 578-584.

Zink, R. M., Rootes, W. L. \& Dittmann, D. L., 1991b. Mitochondrial DNA variation, population structure, and evolution of the Common Grackle (Quiscalus quiscula). Condor 93: 318-329.

Zink, R. M., Dittmann, D. L., Cardiff, S. W. \& Rising, J. D., 1991c. Mitochondrial DNA variation and the taxonomic status of the Large-billed Savannah Sparrow. Condor 93: 1016-1019.

Zink, R. M., Rohwer, S., Andreev, A. V. \& Dittmann, D. L., 1995. Trans-Beringia comparisons of mitochondrial DNA differentiation in birds. Condor 97: 639-649. 